\title{
Invited Synthesis Paper: Principles and practices for managing rangeland invasive plants
}

\author{
ROBERT A. MASTERS AND ROGER L. SHELEY
}

Authors are field development biologist, Dow AgroSciences, 3618 South $75^{\text {th }}$ Street, Lincoln, Nebr. 68506 and associate professor, Department of Land Resources and Environmental Sciences, Montana State University, Bozeman, Montana 59717. At the time this manuscript was submitted, Masters was rangeland scientist, USDA-ARS, 344 Keim Hall, University of Nebraska, Lincoln, Nebr. 68583.

\section{Abstract}

Invasive plants reduce the capacity of ecosystems to provide goods and services required by society, alter ecological processes, and can displace desirable species. They can reduce wildlife habitat quality, riparian area integrity, rangeland economic value, and enterprise net returns. The invasion process is regulated by characteristics of the invading plant and the community being invaded. The presence and spread of invasive plants is often symptomatic of underlying management problems that must be corrected before acceptable, long-term rangeland improvement can be achieved. Disturbance appears to be important early in the invasion process because it creates vacant niches that alien plants can occupy. Control of invasive plants may only open niches for establishment of other undesirable plants unless desirable plants are present to fill the vacated niches. In many instances, rangelands have deteriorated to the point that desirable species are either not present, or in such low abundance that plant community recovery is slow or will not occur without revegetation after invasive plants are controlled. Integrated weed management employs the planned, sequential use of multiple tactics (e.g. chemical, biological, cultural, and mechanical control measures) to improve ecosystem function (energy flow and nutrient cycling) and maintain invasive plant damage below economic levels, and emphasizes managing rangeland ecosystem functions to meet objectives rather than emphasizing a particular weed or control method. Sustainable, integrated invasive plant management strategies require assessing plant impacts, understanding and managing the processes influencing invasion, knowledge of invasive plant biology and ecology, and are based on ecological principles. Invasive plant management programs must be compatible with and integrated into overall rangeland resource management objectives and plans. Because of the complexity of managing invasive plants, it is imperative that relevant ecological and economic information be synthesized into user-friendly decision support systems.

Key Words: Biological control, herbicides, revegetation, native plants, alien plants, restoration, renovation, adaptive management, integrated weed management, noxious weed

This paper is a joint contribution of the USDA-ARS and the Nebraska Agriculture Research Division Journal Series No. 13022.

Manuscript accepted 11 Mar. 01

\section{Resumen}

Las plantas invasoras reducen la capacidad del ecosistema para proveer los bienes y servicios requeridos por la sociedad, alteran los procesos ecológicos y pueden desplazar especies deseables. Ellas también pueden reducir la calidad del hábitat de la fauna silvestre, la integridad de las áreas ribereñas, el valor económico del pastizal y los retornos netos de la empresa. El proceso de invasión es regulado por las características de las plantas invasoras y la comunidad que esta siendo invadida. La presencia y dispersión de las plantas invasoras a menudo es un síntoma de problemas de manejo que deben ser corregidos antes de que se logren mejoras aceptables de largo plazo en el pastizal. El disturbio parece ser importante al inicio del proceso de invasión porque crea nichos vacantes que las plantas invasoras pueden ocupar. El control de plantas invasoras puede solo abrir nichos para el establecimiento de otras plantas indeseables, a menos de que estén presentes plantas deseables para llenar los nichos vacantes. En muchos casos los pastizales se han deteriorado al punto de que las especies deseables o no están presentes o están en una abundancia tan baja que la recuperación de la comunidad es lenta o no ocurrirá sin revegetación después de que las plantas invasoras han sido controladas. El manejo integrado de maleza emplea el uso secuencial planeado de tácticas múltiples (por ejemplo, medidas de control químico, biológico, cultural y mecánico) para mejorar la función del ecosistema (flujo de energía y reciclaje de nutrientes) y mantener el daño de las plantas invasoras abajo de niveles económicos, y enfatiza el manejo de la función del ecosistema de pastizal para cumplir con los objetivos en lugar de enfatizar en una maleza en particular o un método de control especifico.

Las estrategias sustentables del manejo integrado de plantas invasoras requieren de evaluar los impactos de las plantas, entender y manjar el proceso que influye en la invasión, el conocimiento de la ecología y biología de la planta invasora y son basados en principios ecológicos. Los programas de manejo de plantas invasoras deben ser compatibles e integrados dentro del plan y objetivos generales de manejo de los recursos del pastizal. Debido a la complejidad del manejo de las plantas invasoras es imperativo que la información ecológica y económica relevante sea sintetizada en sistemas de soporte de toma de decisiones amigables para el usuario. 
Invasive plants usually have many adverse impacts as they spread through terrestrial and aquatic ecosystems. In the seminal text, The Ecology of Invasions, Elton (1958) described the impact of exotic or non-indigenous organisms invading new environments as "ecological explosions". Many of the estimated 5000 alien plants that now occur in natural ecosystems in the United States (Morse et al. 1995) were introduced for food, fiber, or ornamental purposes (U.S. Congress, Office of Technology Assessment 1993, Pimental et al. 2000). While many of these plants are of great value to agriculture, a small number have become invasive and threaten ecosystems.

Predicting which plants will be invasive and which ecosystems will be invaded is a highly desirable goal, but identification of salient characteristics of invasiveness and invasibility remains illusive (Crawley 1987, Mack 1989, 1996, Rejmanek and Robinson 1996, Wade 1997). Those plants that become invasive disrupt ecosystem processes and reduce the capacity of ecosystems to recover to a desirable state after disturbance and provide the goods and services (Costanza et al. 1997) demanded by society.

The presence and spread of invasive plants on rangeland is often symptomatic of underlying management problems that must be corrected before acceptable longterm progress toward control of the pests and rangeland improvement. Past rangeland management practices and climatic changes have contributed to plant community shifts by altering disturbance regimes that have accelerated invasive plant establishment and expansion (Hobbs 1989, 1991, 2000, Mack 1989, Hobbs and Huenneke 1992, Sutherst 2000).

The use of any single technology to control these species is usually not successful. Removing invasive plant species with chemical or biological control measures may only open niches for other undesirable species to occupy or to be reinvaded by the same species unless desirable species are present to fill the vacated niches. Where desirable species are either not present or in low abundance, plant community recovery will be slow or may not occur without revegetation (Masters et al. 1996, Masters and Nissen 1998).

Instead of relying on a single technology, integrated pest management emphasizes the sequential application of complimentary or synergistic control measures in an economically and ecologically effective manner (Pimentel 1982). Integrated pest management is the coordinated use of multiple tactics to assure stable ecosystem function and maintain pest damage below economic levels, while minimizing hazard to humans, animals, plants, and the environment (U.S. Congress, Office of Technology Assessment 1993). Integrated weed management emphasizes management of rangeland and pasture ecosystem function (energy flow and nutrient cycling) rather than a specific weed or control method (Scifres 1986). With this in mind, the goal of invasive plant management should be to reclaim or restore degraded weed-infested rangeland communities so that they are less susceptible to re-invasion by invasive plants and can meet land use objectives (Masters et al. 1996, Sheley et al. 1996).

Our purpose is to describe principles and practices to consider when developing integrated strategies to manage invasive plants on rangeland. Sustainable integrated invasive plant management strategies require assessing their impacts, understanding and managing the processes influencing invasion, knowledge of invasive plant biology and ecology, and integrating management tactics based on ecological principles. Ultimately, for these strategies to be successful, they must be compatible with and contribute to achieving overall rangeland ecosystem management goals and objectives.

\section{Definitions}

According to the Executive Order 13112 issued by the President of the United States on 3 February 1999, alien species are, with respect to a particular ecosystem, any species, including its propagules that is not native to that ecosystem. Invasive species are alien species whose introduction does or is likely to cause economic or environmental harm or harm to human health. Native species are, with respect to a particular ecosystem, a species that, other than as a result of an introduction, historically occurred or currently occurs in that ecosystem. Cronk and Fuller (1995) considered an invasive plant as an alien plant spreading naturally (without the direct assistance of people) in natural or seminatural habitats, which produces a significant change in terms of composition, structure or ecosystem processes. A noxious weed is an undesirable plant species that is regulated in some way by law (Dewey and Torell 1991, Sheley and Petroff 1999).

\section{Invasive Plant Impacts}

\section{Ecological}

Ecological processes may change after invading species have established and spread (Walker and Smith 1997). These changes may be minimal and the plant invader may simply increase species richness. In contrast, where ecological processes are sufficiently disrupted, native species can be displaced, increasing plant community vulnerability to further invasion and regeneration of the invasive plant. When perturbation of ecosystems exceeds ecological thresholds, ecosystem change can be so profound that controlling the invader may not restore the ecosystem to a desired condition (Hobbs and Humphries 1995). Ecosystem processes, including hydrological cycles (Graf 1978, Loope and Sanchez 1988), erosion and stream sedimentation (Lacey et al. 1989), energy flow and nutrient cycling (Versfeld and van Wilgen 1986, Vitousek and Walker 1989, Stock and Allsopp 1992), native plant regeneration (Tyser and Key 1988, Woods 1993, Belcher and Wilson 1989, Kedzie-Webb et al. 2001), and fire regimes (Hobbs and Atkins 1988, Hughes et al. 1991, Whisenant 1990, D'Antonio and Vitousek 1992) can be altered by alien plant invasions. Cheatgrass (Bromus tectorum L.) invasion in the Intermountain West is thought to have been facilitated by overgrazing (Young and Longland 1996) or by cheatgrass' ability to occupy vacant niches and suppress native species recruitment on areas that have not been overgrazed (Svejcar and Tausch 1991). Cheatgrass proliferation has increased the frequency and intensity of fires occurring in sagebrush grasslands (D'Antonio and Vitousek 1992). This altered fire regime has reduced the abundance of native grasses and shrubs in these grasslands and enabled cheatgrass to dominate. Invasive plants also pose a threat to species designated as threatened or endangered by reducing the quality of natural areas established to protect habitats critical to the survival of these desirable species (Randall 1997).

Invasive plants can reduce wildlife habitat quality. Areas dominated by leafy spurge (Euphorbia esula L.) were used less by deer and bison than non-infested areas (Trammel and Butler 1995). On native bunchgrass sites, dense spotted knapweed (Centaurea maculosa Lam.) populations reduced winter forage available for elk in Montana (Thompson 1996). Elk use of spotted knapweed-infested areas increased $266 \%$ after spotted knap- 
weed was controlled. In the Intermountain West, changes in fire frequency caused by cheatgrass invasions reduced native shrubs that are important for wildlife habitat (Miller et al. 1994).

Riparian areas are some of the most productive range sites in the West, with greater diversity of plant and wildlife species than adjoining lands (Sheley et al. 1995). In healthy riparian systems, vegetation removes sediment from water before it moves into streams. Riparian vegetation absorbs and dissipates the energy of floodwaters, thereby reducing streambank erosion. It also provides critical habitat for terrestrial and aquatic wildlife. Saltcedar (Tamarisk spp.), which has invaded wetlands and riparian streams throughout the western United States, reduces diversity and productivity of the herbaceous understory, and uses large quantities of water (DiTomaso 1998). Dense populations of saltcedar lower water tables, reduce surface water, decrease native vegetation needed by wildlife, and alter frequency of floods.

\section{Economic}

Economic impacts of invasive plants on rangeland have received limited attention (Naylor 2000). The difficulty quantifying the economic value of goods and services provided by ecosystems, i.e., ecological economics (see Saghoff 1995, Daly 1995), further constrains assessment of economic impacts of invasive plants. Attempts have been made to assess the impact of invasive plants on rangeland economic value and enterprise net returns. Bioeconomic models were developed to estimate direct and indirect economic impacts of leafy spurge (Leitch et al. 1996) and spotted knapweed (Hirsh and Leitch 1996). The economic impact of leafy spurge in Montana, North Dakota, South Dakota, and Wyoming is estimated at $\$ 130$ million each year (Leitch et al. 1996). Spotted knapweed costs Montana ranchers an estimated \$11 million annually (Hirsh and Leitch 1996) and if allowed to spread, cost to Montana's livestock industry could exceed $\$ 155$ million each year.

\section{Invasion Process}

Invasive plants can alter ecosystem processes and plant community successional trajectories. When describing the invasion process, it is important to consider invasion as a component of succession. Johnstone (1986) defines succession as the change in species composition over time. The rate and direction of succession

Table 1. General causes of ecological succession, contributing processes, and modifying factors (Pickett et al. 1987).

\begin{tabular}{lll}
\hline \hline General causes & Contributing Process & \multicolumn{1}{c}{ Modifying factors } \\
\hline Site availability & Disturbance & Size, severity, time, dispersion \\
Species availability & Dispersal & Landscape configuration, dispersal agents \\
& Propagules & Land use, time since last disturbance \\
& Resources & Soil, topography, site history \\
Species performance & Ecophysiology & Germination response, assimilation rates, growth \\
& & rates, genetic differentiation \\
& Life history & Allocation, reproductive timing, mode of \\
& reproduction \\
& Stress & Climate, site history, prior occupants \\
& Competition & Competition, herbivory, resource availability \\
& Allelopathy & Soil chemistry, microbes, neighboring species \\
& Herbivory & Climate, predators, plant defenses, patchiness \\
\hline
\end{tabular}

depends on the interaction of species invasion and the reaction of the species in the plant community. Succession is influenced by 3 general factors: site availability; species availability; and species performance (Table 1) (Pickett et al. 1987). These factors are affected by various processes including disturbance and plant:plant and plant:animal interactions that can be modified to alter succession. Succession can be predicted and manipulated with sufficient information about disturbance regime, site, species, and management tools.

A conceptual framework to describe plant invasion can be useful in understanding the invasion process and in making management decisions. Williamson (1996) provided a structure to organize invasion process information. He partitioned the process into 4 phases: (1) arrival and establishment; (2) spread; (3) equilibrium and effects; and (4) implications. Within each of these phases there are specific conceptual points, which further describe the invasion process. The first 3 phases represent the beginning, middle, and end of the process. The fourth phase describes the consequences of invasion on the community or ecosystem.

The invasion process begins with the arrival of alien plant propagules at the new site. Within the last 500 years, movement of alien plants has been accelerated by human-related activities, through intended or non-intended introductions (Crosby 1986, Di Castri 1989). Geographic distances and physical barriers, mountain ranges and oceans, are reduced as impediments to movement of alien species given the increased efficiency and speed with which man transports materials around the world. Mack (1989) indicated that temperate grasslands outside Eurasia have been forever changed by human activities that have facilitated the introduction of alien plants. He wrote, "Few other changes in the distribution of the earth's biota since the end of the Pleistocene have been as radical." Many of the plants that have invaded the New World originated in the Mediterranean Basin and steppes of the Middle East (Heywood 1989). These regions have been subjected to a long history of human habitation and many plants arising from these regions co-evolved with agricultural practices. This association with agricultural production systems has enhanced development of invasive traits in plants. Introductions of alien organisms continue today despite global implementation of quarantine programs for agricultural pests (Mooney and Drake 1989).

Once the alien plant arrives at a new site, community invasion is regulated by characteristics of the invading plant and the existing community (Lawton 1986). Various, often interrelated, hypotheses about species and site invasive characteristics have been generated to provide a framework for ecological theory of invasion (Cronk and Fuller 1995). The absence of predator hypothesis proposes that invasive plants have an advantage because they are introduced into new environments without natural enemies from their native range. The greater reproductive potential hypothesis indicates that invasive plants are more fecund than native species. The poorly adapted native species hypothesis proposes that invasive plants exhibit a greater tolerance to resource constraints than do native species. The chemical change hypothesis suggests that invasive plants are better adapted to altered chemical status of an invaded site. The balance of nature hypothesis is centered on the concept that species-rich communities are more resistant to invasion than species-poor communities. The empty-niche hypothesis contends that invaded communities contain unoccupied niches ready for habitation by invasive plants. The disturbance-produced 
gaps hypothesis suggests that some level of disturbance is necessary to allow an invading species to gain a foothold in a community. These hypotheses provide a foundation upon which to build theory and, ultimately, to predict species invasions.

Attempts to classify species according to their invasiveness have resulted in listings of genetic, physiological, and ecological attributes most often associated with successful invaders (Baker 1965, 1986, Baker and Stebbins 1965, Gray 1986, Lonsdale 1994). Mack (1996) reviewed the advantages and disadvantages of approaches to assess plants invasiveness. These approaches included: listing traits of the invasive plant; characterizing the native range of the invasive plant; developing models to predict invasiveness; quantifying growth characteristics of the invasive plant under different conditions in controlled environments; comparing characteristics of invasive and non-invasive cogeners; and planting the species in the field with and without manipulation of resources. Panetta (1993) and Reichard and Hamilton (1997) suggest that the best predictor of whether or not a species would become invasive in a new environment was its invasiveness elsewhere. Nobel (1989) determined that high population numbers at any life stage in the native environment was a good indicator of invasiveness, while adult and seed longevity and plant perenniality were not reliable indicators of invasive potential. He concluded that knowledge of the invaded environment was as important as the characteristics of the invading species in predicting the invasion process.

To continue the invasion process, alien plant propagules must be dispersed into the new site and arrive at microsites that provide an environment conducive to plant establishment. The location where the immigrant plant can germinate and grow has been referred to as a "safe site" (Harper 1977), "regeneration niche" (Grubb 1977), or "invasion window" (Johnstone 1986). Safe sites meet the requirements of the alien species for germination, growth, and development and enable the plant to reach reproductive maturity.

Disturbance often increases safe site availability for invasive plant establishment (Grubb 1977, Harper 1977, Silvertown 1981, Fox 1985, Hobbs 1991). Various definitions of disturbance have been proposed (Rykiel 1985, Pickett et al. 1987, van Andel and van den Berg 1987, Petraitis et al. 1989, Hobbs and Huenneke 1992). White and Pickett (1985) defined disturbance as any relatively discrete event in time that disrupts ecosystem, community, or population structure, and changes resources, substrate availability, or the physical environment. Events that affect resource availability and community demographic processes such as fire, storms, floods, grazing management, and fertilization are considered to be disturbances. Roads are disturbances that provide corridors for invasive plant dispersal (Lonsdale and Lane 1994, Parendes and Jones 2000) and alter the physical and chemical components of the environment (Trombulak and Frissell 2000), which further facilitate invasion. Disturbances associated with global change (global warming, increasing atmospheric $\mathrm{CO}_{2}$, increasing nitrogen deposition, etc.) will likely influence distributions of invasive plants (Bazzaz 1990, Johnson et al. 1993, Patterson 1995, Vitousek et al. 1997, D’Antonio 2000, Dukes 2000).

Disturbance is an important factor affecting community structure and dynamics (Cooper 1926, Watt 1947, Elton 1958) that promotes invasion by alien plant species (Ewel 1986, Fox and Fox 1986, Hobbs 1989, 1991, Forcella and Harvey 1983, Pickard 1984), especially where disturbance disrupts species interactions and reduces competition (Crawley 1986, 1987, Kruger et al. 1986, Macdonald et al. 1986, Crawley 1987, Orians 1986, Fox and Fox 1986). Invasion success appears to be dependent on the extent and type of disturbance, propagule pressure (number of alien plant propagules in the community and duration of community exposure to propagules) (Rejmanek 1989), and time interval between disturbance events (Hobbs and Huenneke 1992). Community susceptibility to invasion is increased when disturbances deviate from historical patterns because the resident species are not adapted to the new disturbance regime (Burke and Grime 1996). Managing invasive plants requires manipulating the process of disturbance to favor desirable species.

Species diversity may be another factor that influences community invasibility. A commonly cited concept is that community invasibility increases as the number of species decreases (Elton 1958, Rejmanek 1989, Lodge 1993, Tilman 1996, 1997, 1999). Proposed mechanisms that support this premise are that diverse communities have a greater variety of ways to capture resources or possess species that more fully utilize resources than less diverse communities (Naeem et al. 1994, Tilman 1997); therefore, niches are already occupied when a potential invader arrives.
There is evidence that species-rich communities contain a greater number of alien species than species-poor communities (Pickard 1984, Knops et al. 1995, Robinson et al. 1995, Planty-Tabacchi et al. 1996, Palmer and Maurer 1997). Following an analysis of data collected from 184 sites, Lonsdale (1999) determined that communities richer in native species contained more alien plants than species-poor communities. There was no causal relationship between native and invasive plant diversities when measured at the community scale. Low-diversity shortgrass steppe and dry meadow communities were more resistant to invasion than high-diversity wet meadow and riparian communities (Stohlgren et al. 1998, 1999). They suggested that shortgrass steppe and dry meadow communities resist invasion because of the low levels and availability of resources (soil nutrients and water), which are essentially monopolized by the native vegetation. In contrast, high diversity communities are relatively resource rich, and resources become available following disturbance that can be exploited by invading species.

Disturbance appears to be critically important in the beginning of the invasion process because it creates openings for alien plants to occupy. Fluctuations in local species abundance in species-rich communities may provide an opening for alien plants to become established (Peart and Foin 1985). Elton (1958) indicated that the lack of invaders into a given community was the result of competitors, predators, parasites, and diseases that enabled the community to resist invasion. Invasions were successful only when these barriers were reduced or removed by disturbance, or in the case of an alien species, natural enemies were left behind in the native habitats. In contrast, Simberloff (1989) suggested that the vulnerability of a community to invasion was not because of these barriers, but rather the greater frequency of human-mediated introductions of alien species into disturbed communities. Obviously, the invasion process can be affected by a multitude of interacting factors including those described by Elton (1958) and Simberloff (1989).

Once alien species establish, the next phase is their spread through the community (Williamson 1989, Elton 1958, Okubo 1980). An important component of spread is the rate at which the invading species colonizes new sites in the community (Mooney and Drake 1989). Rate of spread is a function of both the alien species characteristics and the characteristics of the ecosystem through which the 
species spreads. Moody and Mack (1988) indicated that the rate of spread of an invader will be geometric if spread is from widely spaced patches versus a linear rate if spread is from a "nascent foci" or single patch. Early in the invasion process there is a lag phase where the invasive plant populations remains small and localized for long periods before expanding exponentially (Fig. 1) (Mack 1985, Auld and Tisdell 1986, Braithwaite et al. 1989, Griffin et al. 1989, Lonsdale 1993, 1999). Hobbs and Humphries (1995) attributed this lag phase to several factors including the time needed for the invading plant to adapt to the site before spreading rapidly, the invading plant's requirement for a specific event or series of disturbance events that facilitate rapid spread, or the invading plant is simply not noticed until it becomes widespread.

\section{Integrated Invasive Plant Management}

Integrated weed management evolved from the concept of integrated pest management in agricultural crops. Integrated pest management was developed by entomologists during the late $1950 \mathrm{~s}$ in response to problems created by excessive use of insecticides (Thill et al. 1991), and was supported by public concerns about environmental consequences of pesticide use that were catalyzed by Rachel Carson's Silent Spring (1962). Integrated pest management has been defined in a number of ways. Two common definitions are that this management strategy involves: (1) a combination of biological, chemical, and cultural methods for maintaining pests below economic crop injury thresholds (Burn et al. 1987, Flint and van den Bosch 1983) or (2) non-chemical pest control measures to reduce reliance on chemical pesticides (Goldstein 1978). Integrated pest management programs should be developed from interdisciplinary efforts that gather information about: (1) the ecological basis of the pest problem; (2) how to make the crop environment unfavorable for pests; (3) when pesticide treatments are needed based on pest and natural enemy populations dynamics; and (4) benefits and risks of the integrated pest management strategy for agriculture and society (Pimental 1982).

Integrated weed management emerged as a viable concept among crop weed scientists in the 1970s. Integrated weed management was defined as the application of technologies in a mutually supportive

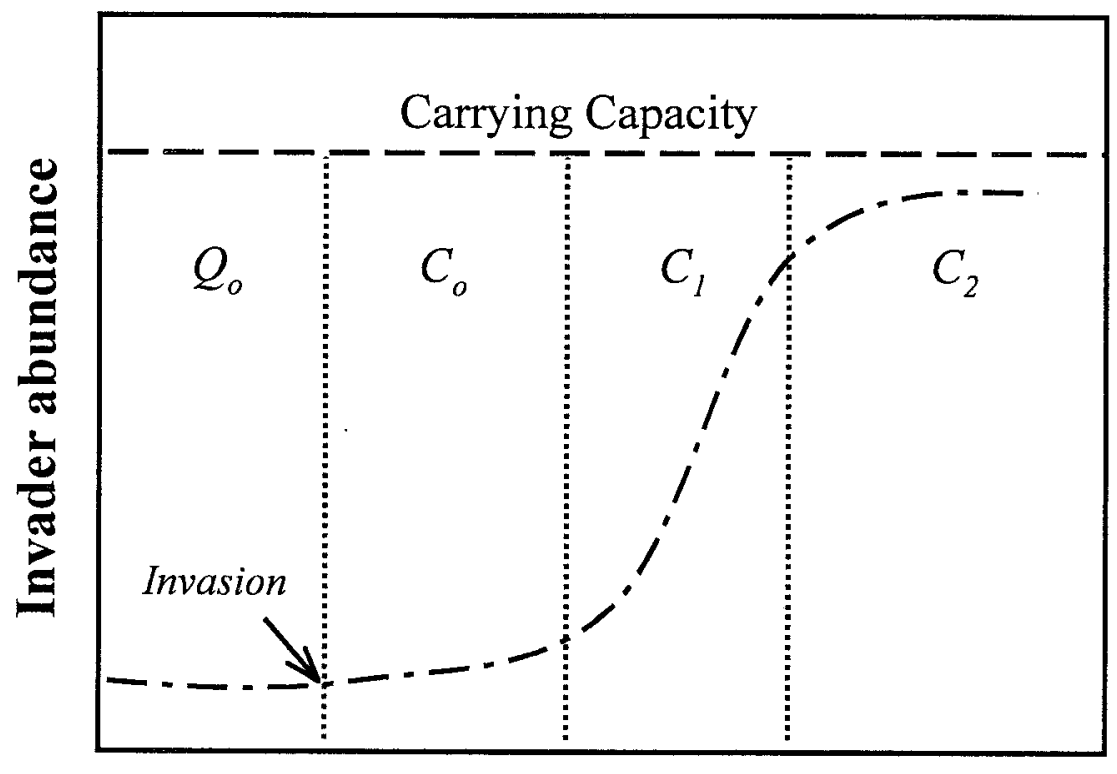

Time

Fig. 1. Phases of weed invasion and priorities for action at each phase: $Q_{0}$-quarantine priority phase; $\mathrm{C}_{0}$-eradication priority stage; $\mathrm{C}_{1}-$ control priority phase (exponential growth phase); $\mathrm{C}_{2}$-maximum population level, effective control unlikely without massive resource inputs. Ease of treatment declines and difficulty and cost increases moving from left to right (Hobbs and Humphries 1995 after Chippendale 1991).

manner, and selected, integrated, and implemented with consideration of economic, ecological, and sociological consequences (Walker and Buchanan 1982). Shaw (1982) indicated that integrated weed management is an approach in which principles, practices, methods, and strategies are chosen to control pests, while minimizing undesirable results. Thill et al. (1991) defined integrated weed management as the integration of effective, environmentally safe, and sociologically acceptable control tactics that reduce weed interference below the economic injury level. Sheley et al. (1996), emphasizing management and not control of noxious rangeland weeds, indicated that integrated weed management strives to use the most economically, ecologically, and environmentally effective combination of principles, technologies, and systems to meet management goals.

Integrated weed management provides a context for managing pests that is ecosystem-centered, and not specific to a species or pest control technology. Frequently, the stated or implied goal of integrated weed management is pesticide-use reduction. We believe that this is not in keeping with the basic concept of integrated weed management, which is a sustainable approach to managing pests by combining biological, cultural, mechanical and chemical tools that minimize economic, health and environmental risks (U.S. Congress, Office of Technology Assessment 1993). Placing value-laden judgements on the various pest management tools and ranking them according to subjective criteria should be avoided. All available tools should be considered during development of integrated weed management programs and those selected should optimize attainment of specific management objectives.

Developing effective integrated weed management programs requires a thorough understanding of the biology and ecology of the invasive plant and invaded community. Information about plant demography, propagule dynamics, seedling recruitment, plant growth and development, and methods of reproduction could help identify vulnerabilities to be exploited in integrated weed management systems (Radosevich et al. 1997). In addition, it is critical that the causes of plant invasion be understood so that they can be alleviated (Hobbs and Norton 1996).

Adapting the basic concepts of integrated weed management on cropland to integrated weed management on rangeland appears relatively straightforward. However, there are differences in management intensity and management objectives between cropland and rangeland that need to be considered. First, monocultures of agronomic species are grown on cropland and are often intentionally disturbed sever- 
al times during the production cycle. Cropland is managed intensively and resource inputs, e.g., pesticides, fertilizer, and cultivation, often improve economic returns. In contrast, rangeland supports heterogeneous mixtures of plant species and is managed extensively. The relatively low value of rangeland per unit area reduces the economic viability of resource inputs compared with cropland. Second, identification of economic thresholds of injury caused by pests are central to development of integrated weed management programs in cropland. Determining economic thresholds for rangeland invasive plants is difficult and has not been adequately addressed. Furthermore, control of rangeland invasive plants designated as noxious is often mandated by law without regard to economic thresholds. Finally, impacts of invasive plants on rangeland ecosystem function and structure may be of more concern than economic impacts, especially on rangeland where other products besides livestock, e.g. wildlife, recreation, aesthetics, and water, are important.

\section{Invasive Plant Management Strategy Components}

The magnitude and complexity of rangeland weeds, combined with the costs for their control, necessitate the use of integrated weed management (Sheley et al. 1996). Education, prevention, detection, monitoring and assessment, and weed control methods are key components of integrated management strategies. Education is an under-emphasized, but important part of invasive plant management. Public awareness about the ecological, environmental, and economic impacts associated with invasive plants may help provide the political support and resources necessary for invasive plant management. Awareness also can promote activities, such as early detection of newly arriving species, in which the general public can participate. On-going educational programs provide practitioners and the general public with knowledge of current management strategies essential to sustainable invasive plant management.

Preventing invader introduction by restricting movement of propagules from infested areas can minimize invader dispersal into new habitats. Early detection followed by swift, intensive, and aggressive implementation of effective control measures during the invasion lag phase (Fig. 1) are essential to eliminate the invader, or at least to prevent seed production (Zamora et al. 1989). Once the invasion process is in the exponential phase, eradication of the invader is usually not a realistic goal. Instead, the emphasis should be to reduce the impact of the invader to an acceptable level and keep the plant from dominating the plant community and substantively altering ecosystem processes. After the invader has reached its maximum abundance, containment of the invader or implementation of intensive restoration efforts may be the only feasible management options.

Monitoring and assessment of invasive plant distributions during invasion and in conjunction with management provides the basic information necessary for planning (Cooksey and Sheley 1997, Johnson 1999). Remote sensing tools such as aerial videography, geographic information systems, global positioning systems, and satellite-borne, narrow-band, multispectral imaging technology have the potential to improve accuracy and reduce the time needed to assess invasive plant distributions (Everitt et al. 1995, 1996a, 1996b, Bork et al. 1998). Time-repeated surveys allow continual assessment of management effectiveness and provide the information necessary to modify strategies to optimize management. Knowledge of invasive and native plant distributions is important for developing invasion risk assessment models based on invasion dynamics, environmental characteristics, and weed dispersal processes.

An adaptive management approach can complement integrated programs to manage invasive plants on rangeland. This approach requires establishing management goals, developing and implementing management programs based on the goals, monitoring and assessing impacts of management efforts, and modifying goals and invasive plant management in light of new information (Schwarz and Randall 1995, Randall 1997). Adaptive management has been developed as an integrated, multidisciplinary approach to deal with the uncertainty associated with natural resource management (Holling 1978, Walters 1986, Gunderson 1999). This approach provides a way to move from a reactive to a proactive mode of invasive plant management.

\section{Weed Control Methods}

Biological. Quimby et al. (1991) defined biological control of weeds as the planned use of living organisms to reduce the plant's reproductive capacity, density, and effect. Biological control can involve any of 3 strategies: conservation; augmentation; and importation of natural enemies (Harley and Forno 1992). Conservation involves manipulation of the environment to enhance the effect of existing natural enemies and is usually used to manage native weeds. Augmentation employs periodic release of natural enemies and is restricted to managing weeds in highvalue food crops because it requires large investments of time and money and repeated intervention. Importation, also known as classical biological control, is the planned relocation of natural enemies of exotic weeds from their native habitats onto weeds in their naturalized habitats. This strategy seeks to reestablish weed and natural enemy interactions that reduce the weed population to an acceptable level (DeBach and Rosen 1990). Synchrony in the life cycles of host plant and agent, adaptation of the agent to a new climate and habitats, ability of the agent to find the host at varying densities, capacity of the agent to reproduce rapidly, and the nature, extent, and timing of the damage caused by the biocontrol agent are among the factors that determine biocontrol agent effectiveness (Louda and Masters 1993).

Success of biological weed control during the past 200 years has been variable. Julien (1992) documented 610 biological control projects that involved 94 weed species in 53 countries. There have been some phenomenally successful biocontrol projects including control of Opuntia spp. in Australia by the moth Cactoblastus cactorum and control of St. Johnswort (Hypericum perforatum L.) in the Pacific Northwest by the beetles, Chrysolina quadrigemina and $C$. hyperici. There are 72 examples worldwide where weed biocontrol programs have been underway for a sufficient period to assess control. Of these programs, $28 \%$ have resulted in control that could be rated as sometimes complete (Sheppard 1992). In contrast, no control was achieved in $35 \%$ of these programs even though biological control agents were established. Important factors that have contributed to the limited success of biological weed control programs include a high level of genetic diversity in the target species, limited compatibility of agents with the invasive plant genotype, and opportunistic predation and parasitism of biocontrol agents in the introduced environment (Sheppard 1992).

The release of imported biological control agents on invasive plants is not without risk (Harris 1988, Howarth 1991, Follett and Duan 1999). By its very nature, classical biocontrol involves release of alien organisms to control other alien organisms and alter botanical composition. The consequences of natural enemy utilization of native relatives of the alien weeds are considered a potentially detri- 
mental side effect of biocontrol (Harris 1988, 1990, Ehler 1990, Howarth 1991). Within a decade after release of 2 beetles, Chrysolina quadrigemina and C. hyperici, to control St. Johnswort (Huffaker and Kennett 1959), larvae of $C$. quadrigemina were found feeding on an introduced ornamental, $H$. calycinum L., and to a limited extent on a related native species, $H$. concinnum Beth (Andres 1985). The seedhead weevil, Rhinocyllus conicus Froel., introduced from Europe into North America to control musk thistle (Carduus nutans L.) (Kok and Surles 1975) has been reared from flowerheads of several native Cirsium species in California (Goeden and Ricker 1986, 1987, Turner et al. 1987). It has also reduced seed production of native Cirsium species at several locations in the central Great Plains (Louda et al. 1997). Once an insect is released into a new environment, little can be done to restrict its distribution or host affinity. Monitoring candidate biological control agents for range expansions, host shifts, and effects on related nontarget plants is critical (Howarth 1991).

Genetic variation in populations of the natural enemy and invasive plant can influence biocontrol program success (Roush 1990). High levels of genetic variability in traits that influence insect impact should increase the probability that the insect will adapt to the new environment. Furthermore, genetic variation extends the range over which the natural enemy can occur and utilize the weed (Harris and Peschken 1971). Identification of important genetic variation and its maintenance in importation, mass-rearing, and release should enhance chances of success. Biological diversity is usually highest in the center of origin of a taxon (Vavilov 1992) and the greatest genetic variation in the natural enemies may be found in the areas of weed origin (Bartlett and Van den Bosch 1964, Zwolfer et al. 1976).

Molecular biology offers tools to quantify invasive plant genetic diversity and to better match natural enemies with the target invasive plant (Nissen et al. 1995, Rowe et al. 1997). Taxonomists, evolutionary biologists and breeders use molecular techniques to measure plant genetic diversity and determine how plants are related. Selected DNA-based molecular marker techniques offer an approach to quantify invasive plant genetic diversity in native and introduced habitats and provide a better understanding of the complex relationships between invasive plants and potential biocontrol agents. This information could provide insights into the geo- graphic origins of invasive plants and provide a means to direct the search for compatible biocontrol agents.

Chemical. Herbicides are assigned to groups according to their chemistry and mode of action (Devine et al. 1993, Ross and Lembi 1999) (Table 2). Mode of action refers to the system, process, or tissue affected by the herbicides. A herbicide is usually selective within certain rates, environmental conditions, and methods of application. Foliar-active herbicides are applied directly to the leaves or stems of plants where they are absorbed and translocated in the plant. These herbicides may or may not remain active once moved into the soil. Soil-active herbicides are absorbed by the roots from the soil water solution. Herbicides can be categorized as to whether they are applied before planti$\mathrm{ng}$ and before (preemergence) or after (postemergence) weed emergence.

Herbicides have been the dominant tools used to control invasive plants on rangeland (Bovey 1995). Potential for ground or surface water contamination, adverse effect on desirable plants, and cost of repeated application to control weeds are some of the concerns associated with herbicide use. The myriad of herbicides currently available, with different modes of action and selectivity, provide land managers with many options to control undesirable plants and manipulate plant composition (Table 2). The most commonly used herbicides on rangeland are auxinlike growth regulators (phenoxy, benzoic, or picolinic acid herbicides) that selectively control broadleaf plants and do not injure grasses when used at recommended rates.

Glyphosate $^{1}$ used on rangeland to control grass and broadleaf weeds, which has no activity in the soil. This is a postemergence herbicide that is translocated within the plant and selectivity is usually determined by the plant growth status. Control is optimized if the target plant is growing at the time of application and negated when the plant is dormant. In the Great Plains, glyphosate was applied in the fall to control cool-season grasses, such as Kentucky bluegrass (Poa pratensis L.) and smooth brome (Bromus inermis L.), but will not injure warm-season grasses that are dormant at application time (Bush et al. 1989).

The imidazolinone and sulfonylurea herbicides: disrupt the synthesis of amino acids, leucine, isoleucine, and valine, that

${ }^{1}$ Refer to Table 2 for chemical names of herbicides mentioned in text. are essential for plant growth and development; are phytotoxic at very low rates; and have low toxicity to vertebrates and invertebrates. Imazapic applied at 140 to $210 \mathrm{~g}$ ai ha ${ }^{-1}$, controls leafy spurge (Masters et al. 1998, Thompson et al. 1998) and is tolerated by many species in the Gramineae, Fabaceae and Compositae families. Another unique attribute of imazapic and other imidazolinone herbicides is the ability to control many annual grass and broadleaf weed species during establishment of desirable native warm-season grasses, forbs, and legumes (Masters et al. 1996, Frye et al. 1997, Rivas-Pantoja et al. 1997, Beran et al. 1999a, 1999b, 2000). Imazapyr controls saltcedar in New Mexico when applied at 0.56 to $0.84 \mathrm{~kg}^{\text {ai }} \mathrm{ha}^{-1}$ in late summer to early fall (Duncan and McDaniel 1998). Sulfometuron is currently registered to control cheatgrass, medusahead [Taeniatherum caput-medusae (L.) Nevski], and cheat (Bromus secalinus L.) on non-cropland administered by state and federal land management agencies in the Intermountain West (EPA Registration No. 352-401).

Cultural. Cultural practices include fire, grazing, revegetation or reseeding, plant competition, and fertilization. These methods are generally aimed at enhancing desirable vegetation to minimize weed invasion.

Fire, along with climate and herbivory, were the primary forces responsible for the formation and maintenance of grassland ecosystems in North America (Wright and Bailey 1982). As with any disturbance, fire effects on ecosystems are influenced by its frequency, intensity, season of occurrence, and interactions with other disturbances. North American grassland fire regimes were shaped by sources of ignition, lightning and humans, and climate (Pyne 1984). Fire is a useful, if not essential, practice to meet management objectives for many plant communities in North America (Wright and Bailey 1982).

Selectivity by herbivores alters competitive interactions within plant communities (Crawley 1983, Luken 1990). In some situations sheep or goat grazing (Bowes and Thomas 1978, Landgraf et al. 1984, Walker et al. 1994, Lym et al. 1997) can control leafy spurge. Appropriate grazing by animals preferring weeds can shift the plant community toward more desired species (Walker 1994, 1995). In contrast, excessive cattle grazing without periodic rest can selectively reduce grass competitiveness, shifting the competitive advantage to weeds (Svejcar and Tausch 1991).

Revegetation with desirable plants may be the best long-term alternative for managing weeds on sites that lack suffi- 
Table 2. Selected herbicides that are currently registered for use on rangeland, pastures, or non-cropland. ${ }^{1}$

\begin{tabular}{|c|c|c|c|c|c|c|}
\hline Chemical group & Common name & Chemical name & Mode of action & $\begin{array}{c}\text { Plants } \\
\text { controlled }^{2}\end{array}$ & Activity $^{3}$ & $\begin{array}{l}\text { Application } \\
\text { timing }^{4}\end{array}$ \\
\hline$\overline{\text { Benzoic acid }}$ & Dicamba & 3,6-dichloro-2-methoxybenzoic acid & $\begin{array}{l}\text { Auxin-type growth } \\
\text { regulator }\end{array}$ & $\mathrm{B}$ & $\mathrm{F}, \mathrm{S}$ & PRE, POST \\
\hline Benzonitrile & Bromoxynil & 3,5-dibromo-4-hydroxybenzonitrile & Photosynthetic inhibitor & $\mathrm{B}$ & $\mathrm{F}$ & POST \\
\hline Bipyridilium & Paraquat & 1,1'-dimethyl-4,4'-bipyridinium ion & $\begin{array}{l}\text { Photosystem } 1 \text { energized } \\
\text { cell membrane disrupter }\end{array}$ & $\mathrm{B}, \mathrm{G}$ & $\mathrm{F}$ & POST \\
\hline Semicarbazones & Diflufenzopyr & $\begin{array}{l}\text { 2-[1-[[[(3,5-difluorophenyl)amino] } \\
\text { carbonyl]hy-drazono]ethyl]-3-pyridine- } \\
\text { carboxylic acid }\end{array}$ & Auxin transport inhibitor & $\mathrm{B}$ & $\mathrm{F}$ & POST \\
\hline \multirow[t]{3}{*}{ Imidazolinone } & Imazethapyr & $\begin{array}{l}\text { 2-[4,5-dihydro-4-methyl-4- } \\
\text { (1-methylethyl)-5-oxo-1H-imidazol-2-yl]- } \\
\text { 5-ethyl-3-pyridinecarboxylic acid }\end{array}$ & $\begin{array}{l}\text { Branched-chain amino } \\
\text { acid inhibitor }\end{array}$ & $\mathrm{B}, \mathrm{G}$ & $\mathrm{F}, \mathrm{S}$ & PRE, POST \\
\hline & Imazapyr & $\begin{array}{l}\text { 2-[4,5-dihydro-4-methyl-4- } \\
\text { (1-methylethyl)-5-oxo-1H-imidazol-2-yl]- } \\
\text { 3-pyridinecarboxylic acid }\end{array}$ & $\begin{array}{l}\text { Branched-chain aminor } \\
\text { acid inhibitor }\end{array}$ & $\mathrm{B}, \mathrm{G}$ & $\mathrm{F}, \mathrm{S}$ & PRE, POST \\
\hline & Imazapic & $\begin{array}{l}\text { 2-[4,5-dihydro-4-methyl-4-(1-methylethyl)- } \\
\text { 5-oxo-1H-imidazol-2-yl]-5-methyl-3- } \\
\text { pyridinecarboxylic acid }\end{array}$ & $\begin{array}{l}\text { Branched-chain amino } \\
\text { acid inhibitor }\end{array}$ & $\mathrm{B}, \mathrm{G}$ & $\mathrm{F}, \mathrm{S}$ & PRE, POST \\
\hline \multirow[t]{3}{*}{ Phenoxy acid } & $2,4-\mathrm{D}$ & (2,4-dichlorophenoxy)acetic acid & Auxin-type growth regulator & B & $\mathrm{F}$ & POST \\
\hline & 2,4-DB & 4-(2,4-dichlorophenoxy)butanoic acid & Auxin-type growth regulator & $\mathrm{B}$ & $\mathrm{F}$ & POST \\
\hline & MCPA & (4-chloro-2-methylphenoxy)acetic acid & Auxin-type growth regulator & B & $\mathrm{F}$ & POST \\
\hline Phenylurea & $\begin{array}{l}\text { Diuron } \\
\text { Tebuthiuron }\end{array}$ & $\begin{array}{l}\text { N'-(3,4-dichlorophenyl)-N,N-dimethylurea } \\
\text { N-[5-(1,1-dimethylethyl)-1,3,4-thiadiazol- } \\
\text { 2-yl]-N,N'-dimethylurea }\end{array}$ & $\begin{array}{l}\text { Photosynthetic inhibitor } \\
\text { Photosynthetic inhibitor }\end{array}$ & $\begin{array}{l}\mathrm{B}, \mathrm{G} \\
\mathrm{B}, \mathrm{G}\end{array}$ & $\begin{array}{l}\text { F, S } \\
\text { F, S }\end{array}$ & $\begin{array}{l}\text { PRE, POST } \\
\text { PRE, POST }\end{array}$ \\
\hline \multirow[t]{2}{*}{ Picolinic acid } & $\begin{array}{l}\text { Clopyralid } \\
\text { Picloram }\end{array}$ & $\begin{array}{l}\text { 3,6-dichloro-2-pyridinecarboxylic acid } \\
\text { 4-amino-3,5,6-trichloro-2-pyridine- } \\
\text { carboxylic acid }\end{array}$ & $\begin{array}{l}\text { Auxin-type growth regulator } \\
\text { Auxin-type growth regulator }\end{array}$ & $\begin{array}{l}\mathrm{B} \\
\mathrm{B}\end{array}$ & $\begin{array}{l}\text { F, S } \\
\text { F, S }\end{array}$ & $\begin{array}{l}\text { PRE, POST } \\
\text { PRE, POST }\end{array}$ \\
\hline & Triclopyr & [(3,5,6-trichloro-2-pyridinyl)oxy]acetic acid & Auxin-type growth regulator & B & $\mathrm{F}, \mathrm{S}$ & PRE, POST \\
\hline \multirow[t]{3}{*}{$s$-Triazine } & Atrazine & $\begin{array}{l}\text { 6-chloro-N-ethyl-N'-(1-methylethyl)-1,3,5- } \\
\text { triazine-2,4-diamine }\end{array}$ & Photosynthetic inhibitor & $\mathrm{B}, \mathrm{G}$ & $\mathrm{F}, \mathrm{S}$ & PRE, POST \\
\hline & Hexazinone & $\begin{array}{l}\text { 3-cyclohexyl-6-(dimethylamino)-1-methyl- } \\
\text { 1,3,5-triazine-2,4(1H,3H)-dione }\end{array}$ & Photosynthetic inhibitor & $\mathrm{B}, \mathrm{G}$ & $\mathrm{F}, \mathrm{S}$ & PRE, POST \\
\hline & Simazine & $\begin{array}{l}\text { 6-chloro-N,N'-diethyl-1,3,5-triazine- } \\
\text { 2,4-diamine }\end{array}$ & Photosynthetic inhibitor & $\mathrm{B}, \mathrm{G}$ & $\mathrm{F}, \mathrm{S}$ & PRE, POST \\
\hline \multirow[t]{3}{*}{ Sulfonyl urea } & Chlorsulfuron & $\begin{array}{l}\text { 2-chloro-N-[[(4-methoxy-6-methyl-1,3,5- } \\
\text { triazin- 2-yl)amino]carbonyl] } \\
\text { benzenesulfonamide }\end{array}$ & $\begin{array}{l}\text { Branched-chain amino } \\
\text { acid inhibitor }\end{array}$ & $\mathrm{B}, \mathrm{G}$ & $\mathrm{F}, \mathrm{S}$ & PRE, POST \\
\hline & Metsulfuron & $\begin{array}{l}\text { 2-[[[[(4-methoxy-6-methyl-1,3,5-triazin- } \\
\text { 2-yl) amino] carbonyl]amino] sulfonyl] } \\
\text { benzoic acid }\end{array}$ & $\begin{array}{l}\text { Branched-chain amino } \\
\text { acid inhibitor }\end{array}$ & $\mathrm{B}, \mathrm{G}$ & $\mathrm{F}, \mathrm{S}$ & PRE, POST \\
\hline & Sulfometuron & $\begin{array}{l}\text { 2-[[[[(4,6-dimethyl-2-pyrimidinyl)amino] } \\
\text { car-bonyl] amino]sulfonyl]benzoic acid }\end{array}$ & $\begin{array}{l}\text { Branched-chain amino } \\
\text { acid inhibitor }\end{array}$ & $\mathrm{B}, \mathrm{G}$ & $\mathrm{F}, \mathrm{S}$ & PRE, POST \\
\hline Uracil & Bromacil & $\begin{array}{l}\text { 5-bromo-6-methyl-3-(1-methylpropyl)- } \\
\text { 2,4(1H, 3H)pyrimidinedione }\end{array}$ & Photosynthetic inhibitor & $\mathrm{B}, \mathrm{G}$ & $\mathrm{F}, \mathrm{S}$ & PRE, POST \\
\hline \multirow[t]{3}{*}{ Unassigned } & Fosamine & ethyl hydrogen (aminocarbonyl)phosphonate & Unknown & $\mathrm{B}$ & $\mathrm{F}$ & POST \\
\hline & Glyphosate & $\mathrm{N}$-(phosphonomethyl)glycine & $\begin{array}{l}\text { Aromatic amino } \\
\text { acid inhibitor }\end{array}$ & $\mathrm{B}, \mathrm{G}$ & $\mathrm{F}, \mathrm{S}$ & POST \\
\hline & Quinclorac & 3,7-dichloro-8-quinolinecarboxylic acid & Cell wall formation inhibitor & or $B, G$ & $\mathrm{~F}, \mathrm{~S}$ & PRE, POST \\
\hline
\end{tabular}

Chemical group and mode of action from Ross and Lembi (1999) and common name and chemical names from (Weed Science Society of America 1994).

${ }_{3}^{2} \mathrm{~B}=$ broadleaf species and $\mathrm{G}=$ grass species

${ }^{3} \mathrm{~F}=$ taken up by plant foliage and $\mathrm{S}=$ has activity in the soil

${ }^{4} \mathrm{PRE}=$ applied before plant emerges and POST $=$ applied after plant emerges

cient abundance of desirable species. Establishing competitive grasses, forbs, and legumes may suppress invasive plants, enhance plant community resistance to further invasion, and improve forage production and quality (Masters et al. 1996, Lym and Tober 1997, Bottoms and Whitson 1998, Ferrell et al. 1998, Masters and
Nissen 1998, Whitson and Koch 1998).

Selecting plant species is a critical consideration when developing a desired plant community if the desirable species are not present in sufficient abundance to enable regeneration within an acceptable timeframe. Jones and Johnson (1998) described an integrated approach for mak- ing decisions about how to select plant materials for rangeland revegetation. Site potential, desired landscape, seeding objectives, conflicting land-use philosophies, appropriate plant materials, invasive plants, community seral status, and economic limitations are key components of the decision-making process. 
Table 3. Examples of integrated strategies for control of invasive plants on rangeland (modified after DiTomaso 2000).

\begin{tabular}{|c|c|c|}
\hline Invasive Plant & Strategy components & Citation \\
\hline Acroptilon repens (L.) DC & Tillage, herbicide, and revegetation & $\begin{array}{l}\text { Dershied et al. 1963, Bottoms and Whitson 1998, } \\
\text { Benz et al. } 1999\end{array}$ \\
\hline Bromus tectorum $L$. & Tillage, herbicide, and revegetation & $\begin{array}{l}\text { Eckert and Evans 1967, Evans et al. } 1967 \\
\text { Whitson and Koch } 1998\end{array}$ \\
\hline Centaurea spp. & $\begin{array}{l}\text { Herbicide and grazing } \\
\text { Herbicide, revegetation, and biocontrol } \\
\text { Herbicide and revegetation } \\
\text { Burning and herbicide }\end{array}$ & $\begin{array}{l}\text { Whitson and Koch } 1998 \\
\text { Enloe and DiTomaso } 1999 \\
\text { Sheley et al. } 2001 \\
\text { Lacey et al. } 1995\end{array}$ \\
\hline Cirsium arvense (L.) Scop. & Herbicide and revegetation & Wilson and Kachman 1999 \\
\hline Euphorbia esula L. & $\begin{array}{l}\text { Herbicide and biocontrol } \\
\text { Tillage, herbicide, and revegetation } \\
\text { Tillage, herbicide, and fertilization } \\
\text { Grazing and herbicide } \\
\text { Herbicide, burning, and revegetation }\end{array}$ & $\begin{array}{l}\text { Nelson et al. } 1998 \\
\text { Selleck et al. } 1962 \text {, Ferrell et al. } 1998 \\
\text { Lym and Tober } 1997 \\
\text { Lym and Messersmith } 1993 \\
\text { Lym et al. } 1997 \\
\text { Masters and Nissen 1998, Masters et al. } 2001\end{array}$ \\
\hline Hypericum perforatum $L$. & Tillage and revegetation & Gates and Robocker 1960 \\
\hline Lepidium latifolium L. & Mowing and herbicide & Renz and DiTomasa 1999 \\
\hline Linaria dalmatica (L.) Mill. & Tillage and revegetation & Gates and Robocker 1960 \\
\hline Opuntia stricta (Haworth) Haworth & Herbicide and biocontrol & Hoffman et al. 1998 \\
\hline Taeniatherum caput-medusae (L.) Nevski & $\begin{array}{l}\text { Burning, herbicide, and revegetation } \\
\text { Tillage, herbicide, and revegetation }\end{array}$ & $\begin{array}{l}\text { Horton } 1991 \\
\text { Young et al. } 1969\end{array}$ \\
\hline
\end{tabular}

A question faced by land managers considering revegetation is whether to use native and/or introduced plant materials (Lesica and Allendorf 1999). The value of local ecotypes (Knapp and Rice 1994, Linhart and Grant 1996), native or introduced plant cultivars with improved agronomic traits developed by formal breeding programs (Vogel et al. 1989, Vogel 2000, Casler et al. 1996), and mixed populations or hybrid genotypes (Millar and Libby 1989, Munda and Smith 1995) in revegetation programs has been detailed. Another perspective is that rather than emphasizing individual species, the focus of revegetation programs should be on establishing functional groups (Walker 1992) that maintain ecosystem processes (Noss 1991). Johnson and Mayeux (1992) argue that no special quality should be attributed to a species labeled as a "native," rather the focus should be on ecosystems as "self-sustaining systems in terms of physiognomic structure and functional processes in which various species ..... are interchangeable."

Mechanical. Mechanical treatments involve either removal of the aerial portions of the weed or removal of enough of the root and crown to kill the plant. Annuals and some biennials and perennials can be suppressed or controlled if mowing occurs before fruits mature and viable seeds form. Mowing in the fall for 3 consecutive years decreased spotted knapweed density about $85 \%$ compared to areas that were not mowed (Rinella et al. 2001). Mowing perennial herbaceous or woody plants that have the capability to reproduce vegetatively can actually exacerbate weed interference by stimulating production of new stems from vegetative buds below the cut surface. However, perennial plants that reproduce vegetatively can be severely damaged or killed by tillage (Derscheid et al. 1985), bulldozing, root-plowing, or grubbing (Vallentine 1989). The high cost of these mechanical treatments limits their use to control rangeland weeds.

\section{Integrating Multiple Weed Control Strategies}

There are several examples of integrated strategies used to manage invasive plants and improve rangeland communities (Table 3 ). Efforts to assess the compatibility of insect biocontrol agents and herbicides during development of integrated management systems are increasing (Messersmith and Adkins 1995). Revegetation has been a common component of integrated approaches because it is essential that desirable plant species, rather than another invasive plant species, fill the niche vacated by the controlled invader. Herbicides and tillage were used to suppress dalmation toadflax (Linaria dalmatica Mill.) and St. Johnswort (Gates and Robocker 1960), cheatgrass (Eckert and Evans et al. 1967), and medusahead (Young et al. 1969) in early attempts to prepare degraded rangeland sites for revegetation with cool-season grasses.

Approaches that include herbicide application and establishing monoculture stands of introduced and native perennial grasses have been successfully used to suppress leafy spurge and improve forage production on rangeland. In Wyoming, seedbed preparation consisted of multiple glyphosate applications in spring and summer followed by tillage before planting introduced cool-season grasses (Ferrell et al. 1998). Introduced cool-season grasses were planted in a tilled seedbed following broadcast applications of glyphosate and 2,4-D in North Dakota (Lym and Tober 1997). The planted grasses that were most effective in suppressing leafy spurge were 'Bozoisky' Russian wildrye [Psathyrostachys juncea (Fisch.) Nevski] and 'Luna' pubescent wheatgrass [Elytrigia intermedia (Host) Beauv.] in Wyoming, and 'Rebound' smooth brome and 'Reliant' intermediate wheatgrass [Thinopyrum intermedium (Host) Barkw. \& D.R. Dewey] in North Dakota. In Nebraska, monoculture stands of native warm-season grasses, big bluestem (Andropogon gerardii Vitman), indiangrass [Sorghastrum nutans (L.) Nash], and switchgrass (Panicum virgatum L.), were established on leafy spurgeinfested rangeland and increased herbage yields by more than $40 \%$ and reduced leafy spurge density and yield (Masters and Nissen 1998). The sites were treated with imazapyr and sulfometuron in the fall and burned the following spring before tallgrasses were planted into the herbicidesuppressed sod without tillage.

Recent rangeland improvement research demonstrated an integrated weed manage- 
ment strategy, which suppressed leafy spurge and associated vegetation and facilitated planting and establishment of stands of mixture of native warm-season grass and legume species (Masters et al. 2001). These multi-species assemblages may more fully use resources on degraded rangeland and preempt resource use by less desirable species, including leafy spurge. The strategy consisted of herbicide application, burning the herbaceous standing crop, and planting mixtures of native species without tillage. Glyphosate and imazapic were the herbicides selected to suppress existing resident vegetation, while not interfering with establishment of species in the planted mixtures. Glyphosate controlled cool-season grasses that were growing at the time of application, but provided no residual weed control. Imazapic provided residual control of leafy spurge and annual grass and broadleaf plants and was tolerated by a number of warm-season grasses (RivasPantoja et al. 1997, Beran et al. 2000), forbs (Beran et al. 1999a) and legumes (Beran et al. 1999b).

\section{Invasive Plant Management Systems as a Component of Rangeland Resource Management}

To be successful, invasive plant management programs must be compatible with and integrated into overall rangeland resource management objectives and plans. Effective invasive plant management programs cannot be developed without considering other management components that impinge upon the rangeland resource. Integrating all components within the rangeland resource management program is essential because interactions among the components determine the economic and ecological sustainability of the program. For example, altering grazing management or fire regimes impact site invasibility since the invasion process can be influenced by disturbance.

What is the appropriate goal when developing rangeland resource management programs? The "desired plant community" could serve as the goal for rangeland resource management. The desired plant community concept originated with the USDI-Bureau of Land Management and was defined by the Society for Range Management, Task Group on Unity in Concepts and Terminology (1995) as, "of the several plant communities that may occupy a site, the one that has been identified through a management plan to best meet the plan's objectives for the site. It (the desired plant community) must pro- tect the site at a minimum." This concept recognizes that plant community succession for a given site can progress along multiple trajectories and result in different outcomes. Factors that influence these outcomes include past management, plant and animal dispersal from adjacent areas, climatic conditions, disturbance regimes (past, present, and future), and species selected for revegetation projects. The desired plant community concept is consistent with prevailing state and transition (Westoby et al. 1989) and threshold (Laycock 1991, Friedel 1991) models of vegetation change. These non-equilibrium models of succession have superceded the unidirectional Clementsian climax community model (Clements 1916, Weaver and Clements 1938).

The desired plant community is an appealing concept for rangeland management because it empowers land managers to design a plant community that meets management objectives. In the context of invasive plant management, resistance to alien plant invasion would be a key criterion considered when designing a desired plant community. Obtaining the desired plant community involves managing succession, which requires knowledge of the 3 general causes of succession: site availability; differential species availability; and species performance (Table 1) (Pickett et al. 1987, Luken 1990). Within the limits of knowledge about the conditions, mechanisms, and processes controlling plant community dynamics, these 3 components can be modified to manage succession by using designed disturbance, controlled colonization, and controlled species performance (Pickett et al. 1987). Designed disturbances include activities that create or eliminate site availability and control succession such as tillage or herbicide suppression of sod. In successional management, designed disturbances are used to alter successional trajectories and to minimize continual reliance on external inputs. Controlled colonization is the intentional alteration of availability and establishment of plant species by influencing seed banks, vegetative propagule pools, and regulation of safe sites for germination and establishment of desirable species. Invasive plant seed banks can be depleted through attrition if seed production is prevented or reduced. Controlled species performance involves manipulating growth and reproduction of plant species to redirect succession. Biological and chemical weed control, grazing, mowing, fertilization, and planting competitive species can create differential species performance. Management of succession is an ongoing process moving along a trajectory that is driven by both naturally occurring and human-induced processes. A generalized model describes the process of managing succession by using various management tools in appropriate sequences and combinations to achieve a desired grassland community structure (Fig. 2) (Masters and Nissen 1998).

The restoration ecology discipline provides goals to consider when developing and implementing strategies to manipulate community succession to meet management objectives. Restoration has been distinguished from or referred to interchangeably with rehabilitation, reclamation, reconstruction, renovation, and other terms (Whisenant 1999). The Society for Ecological Restoration (1994) defined restoration as the process of repairing damage caused by humans to the diversity and dynamics of indigenous ecosystems, and Jackson et al. (1995) provide further elaboration of the definition. Hobbs and Norton (1996) suggest a broader definition, with restoration occurring along a continuum from rebuilding totally devastated sites to maintaining pristine sites with limited management. They indicate that restoration should be applied at the landscape scale and the goal should be to return degraded ecosystems to conditions that meet conservation and production objectives in a sustainable manner.

\section{Decision Support Systems}

Invasive plant management is complex, thus all applicable information should be synthesized and presented in a way that is useful to managers. Decision support systems offer an approach to improve decision making when complex interactions are involved (Stuth and Smith 1993). Expert systems, a form of decision support systems, can improve decision making by using knowledge and experience of experts to provide users a means to assess alternative management outcomes based on specific information about the situation (Barrett and Jones 1989). Many decision support systems use heuristic ("rule of thumb") approaches to problem-solving that blend hard data with semi-structured procedures and expertise to provide information required to define a problem and possible solutions (Scifres 1987, Stuth and Smith 1993). The integrated brush management system concept developed by Scifres et al. (1983) provides a system to evaluate integrated management with multiple objectives and components. These models could be of great benefit in developing decision support systems for invasive plant management programs. 


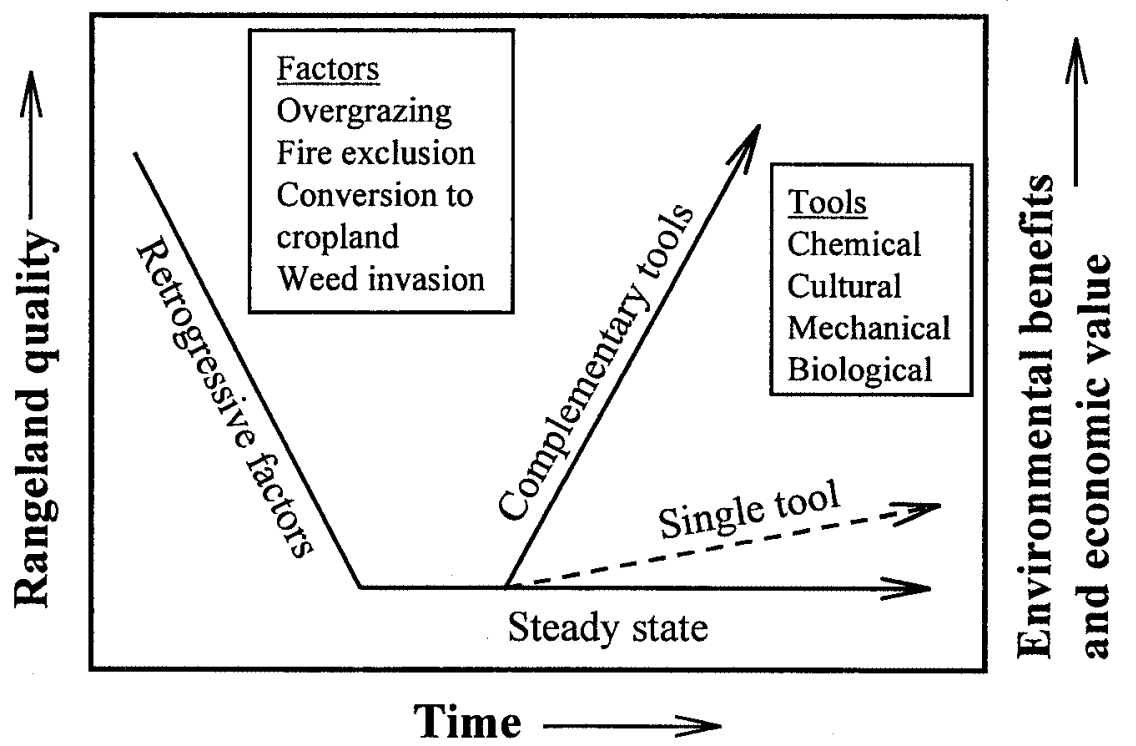

Fig. 2. Generalized community succession model for Great Plains grasslands. Retrogression leads to a steady state condition of low productivity. Reliance on a single technology results in slow grassland recovery rate. Sequential application of complementary and possibly synergistic technologies accelerates progress towards higher quality rangeland (Masters and Nissen 1998).

\section{Conclusion}

Invasive plants can have adverse effects on rangeland and pasture ecosystems by disrupting ecosystem processes and reducing their capacity to recover after disturbance. Disturbance is an important factor affecting community structure and dynamics, and facilitates alien plant invasion. Managing invasive plants requires manipulating disturbance regimes to favor desirable species. Various technologies are available for managing invasive plants, but acceptable long-term control will only be achieved when integrated weed management programs are integrated into rangeland resource management plans. Integrated weed management provides a context for managing pests that focuses on ecosystem processes and not on particular plant species or control practices. The advantages and disadvantages of weed control tools will vary according to the invasive plant and invaded site characteristics. The merits of each control measure and the potential for complementary or synergistic interactions when applying measures in appropriate sequences and combinations should be considered when developing integrated weed management programs. The reasons for the arrival, establishment, and spread of invasive plants must be understood before sustained progress can be made toward controlling the plant and improving rangeland and pasture ecosystems. Simply removing

\section{Literature Cited}

Andres, L. A. 1985. Interactions of Chrysolina quadrigemina and Hypericum spp. in California. p. 235-239. In: E. S. Delfosse, (ed.), Proceedings. of the $\mathrm{VI}^{\text {th }}$ International Symposium. on the biological control of weeds. Agr. Canada, Ottawa.

Auld, B.A. and C.A. Tisdell. 1986. Impact assessment of biological invasions. p. 79-88. In: R.H. Groves and J.J. Burdon (eds.), Ecology of biological invasions. Cambridge Univ. Press, Cambridge, England.

Baker, H.G. 1965. Characteristics and modes of origin of weeds, p. 147-169. In: H.G. Baker and C.L. Stebbins (eds). The genetics of colonizing species. Academic Press, New York.

Baker, H.G. 1986. Patterns of invasions in North America, p. 44-57. In: H.A. Mooney and J.A. Drake (eds.), Ecology of biological invasions of North America and Hawaii. Springer-Verlag, N.Y.

Baker, H.G. and C.L. Stebbins. 1965. The genetics of colonizing species. Academic Press, N.Y.

Barrett, J. R. and D. D. Jones. 1989. Knowledge engineering in agriculture. Monogr. 8. Amer. Soc. Agr. Engineers

Bartlett, B.R. and R. Van den Bosch. 1964. Foreign exploration for beneficial organisms, p. 283-304. In: P. DeBach (ed.), Biological control of insect pests and weeds. Chapman \& Hall, London, England.

Bazzaz, F.A. 1990. The response of natural ecosystems to the rising global $\mathrm{CO}_{2}$ level. Annu. Rev. Ecol. Syst. 21:167-196.

Belcher, J.W. and S.D. Wilson. 1989. Leafy spurge and the species composition of a mixed-grass prairie. J. Range Manage. 42:172-175.

Benz, L.J., G. Beck, T.D. Whitson, and D.W. Koch. 1999. Reclaiming Russian knapweed infested rangeland. J. Range Manage. $52: 351-356$.

Beran, D.D., R.E. Gaussoin, and R.A. Masters. 1999a. Native wildflower establishment with imidazolinone herbicides. HortSci. 34:283-286.

Beran, D.D., R.A. Masters, and R.E. Gaussoin. 1999b. Grassland legume establishment with imazethapyr and imazapic. Agron. J. 91:592-596.

Beran, D.D., R.A. Masters, R.E. Gaussoin, F. Rivas-Pantoja. 2000. Establishment of big bluestem and Illinois bundleflower mixtures with imazapic and imazethapyr. Agron. J. 92:460-465.

Bork, E.W., N.E. West, and K.P. Price. 1998. In situ narrow-band reflectance characteristics of cover components in sagebrushsteppe. Geocarta Int. 13:5-15.

Bottoms, R.M. and T.D. Whitson. 1998. A systems approach for the management of Russian knapweed (Centaurea repens). Weed Technol. 12:363-366.

Bovey, R.W. 1995. Weed management systems for rangelands. p. 519-552. In: A.E. Smith (ed.), Handbook of weed management systems. Marcel Dekker, Inc. New York, N.Y. 
Bowes, G.G. and A.G. Thomas. 1978 . Longevity of leafy spurge seeds in the soil following various control programs. J. Range Manage. 31:137-140.

Braithwaite, R.W., W.M. Lonsdale, and J.A. Estbergs. 1989. Alien vegetation and native biota in tropical Australia: the spread of Mimosa pigra. Biol. Conserv. 48:189-210.

Burke, M.J.W. and J.P. Grime. 1996. An experimental study of plant community invasibility. Ecol. 77:776-790.

Burn, A.J., T.H. Coaker, and P.C. Jepson. 1987. Integrated pest management Academic Press, San Diego, Calif

Bush, B.L., S.S. Waller, B.E. Anderson, L.E. Moser, and R.M. Wozniak. 1989. Sod seeding warm-season grass with and without sod suppression, p. 75-79. In: T. Bragg and J. Stubbendieck (eds.), Proceedings $12^{\text {th }}$ North American Prairie Conference. Lincoln, Nebr.

Carson, R. 1962. Silent spring. Fawcett Publ. Greenwich, Conn.

Casler, M.D., J.F. Pedersen, G.C. Eizenga, and S.D. Stratton. 1996. Germplasm and cultivar development,. p. 413-469. In: L.E. Moser, D.R. Buxton, and M.D. Casler, (eds.) Cool-Season Forage Grasses. Agron. Soc. Amer. Monogr. No. 34

Chippendale, J.F. 1991. Potential returns to research on rubber vine (Cryptostegia grandiflora). M.S. Thesis, Univ. of Queensland, Brisbane, Australia.

Clements, F.E. 1916. Plant succession: An analysis of the development of vegetation. Carnegie Inst. Pub. 242. Washington, D.C.

Cooksey, D. and R.L. Sheley. 1997. Montana noxious weed survey and mapping system. Montana State University Cooperative Extension Service, MT 9613, Bozeman, Mont.

Cooper, W.S. 1926. The fundamentals of vegetation change. Ecol. 7:391-413.

Costanza, R., R. d'Arge, R. de Groot, S. Farber, M. Grasso, B. Hannon, K. Limburg, S. Naeem, R.V. O'Neill, J. Paruelo, R.G. Raskin, P. Sutton, and $M$. van den Belt. 1997. The value of the word's ecosystem services and natural capital. Nature 387:253-260.

Crawley, M.J. 1983. Herbivory: the dynamics of animal-plant interactions. Blackwell Sci. Publ. Oxford, England.

Crawley, M.J. 1986. The populations biology of invaders. Phil. Trans. Roy. Soc. London. B 314:711-731.

Crawley, M.J. 1987. What makes a community invasible? p. 429-454. In: M.J. Crawley, P.J. Edwards, and A.J. Gray (eds.), Colonization, succession, and stability. Blackwell, Oxford, England.

Cronk, Q.C.B. and J.L. Fuller. 1995. Plant Invaders: The Threat to Natural Systems. Chapman \& Hall, London.

Crosby, A.W. 1986. Ecological imperialism: the biological expansion of Europe, 9001900. Cambridge University Press, Cambridge, England.

Daly, H.E. 1995. Reply to Mark Saghoff's "Carrying capacity and ecological economics.” BioSci. 45:621-624.
D'Antonio, C.M. and P.M. Vitousek. 1992. Biological invasions by exotic grasses, the grass/fire cycle, and global change. Annu. Rev. Ecol. Syst. 23:63-87.

D'Antonio, C.M. 2000. Fire, plant invasions, and global changes. p. 65-94. In: H.A. Mooney and R.J. Hobbs (eds.), Invasive species in a changing world. Island Press, Washington, D.C

DeBach, P. and D. Rosen. 1990. Maximizing biological control through research, p. 259-302. In: P. DeBach and D. Rosen (eds.), Biological control with natural enemies. Cambridge Univ. Press, New York, N.Y.

Derscheid, L.A., K.E. Wallace, and R.L. Nash. 1963. Russian knapweed control with cultivation, cropping, and chemicals. Weeds 8:268-278.

Derschied, L.A., L.J. Wrage, and W.E. Arnold. 1985. Cultural control of leafy spurge,. p. 57-64. In: A.K. Watson (ed.), Leafy spurge. Monogr. No. 3, Weed Sci. Soc. Amer., Champaign, Ill.

Devine, M., S.O. Duke, and C. Fedtke. 1993. Physiology of herbicide action. Prentice Hall, Englewood Cliffs, N.J.

Dewey, S.A. and J.M. Torell. 1991. What is a noxious weed? p. 1-4. In: L.F. James, J.O. Evans, M.H. Ralphs, and R.D. Child (eds.), Noxious range weeds. Westview Press, San Franciso, Calif.

Di Castri, F. 1989. History of biological invasions with special emphasis on the old world, p. 1-30. In: J.A. Drake, H.A. Mooney, F. Di Castri, R.H. Groves, F.J. Kruger, M. Rejmanek, and M. Williamson (eds.), Biological invasions: a global perspective. John Wiley \& Sons, New York, N.Y.

DiTomaso, J.M. 1998. Impact, biology, and ecology of saltcedar (Tamarisk spp.) in the southwestern United States. Weed Technol. 12:326-336

DiTomaso, J.M. 2000. Invasive weeds in rangelands: species, impacts, and management. Weed Sci. 48:255-265.

Dukes, J.S. 2000. Will increasing atmospheric $\mathrm{CO}_{2}$ concentration affect the success of invasive species? p. 95-114. In: H.A. Mooney and R.J. Hobbs (eds.), Invasive species in a changing world. Island Press, Washington, D.C.

Duncan, K.W. and K.C. McDaniel. 1998. Saltcedar (Tamarix spp.) management with imazapyr. Weed Technol. 12:337-344.

Ehler, L.E. 1990. Introduction strategies in biological control of insects,. p. 111-134. In: M. Mackauer, L.E. Ehler, and J. Roland (eds.), Critical Issues in Biological Control. Intercept, Andover, England.

Eckert, R.E. and R.A. Evans. 1967. A chemical-fallow technique for control of downy brome and establishment of perennial grasses on rangeland. J. Range Manage. 20:35-41.

Elton, C.S. 1958. The ecology of invasions by animals and plants. John Wiley \& Sons, Inc., N.Y.

Enloe, S. and J. DiTomaso. 1999. Integrated management of yellow starthistle on California rangeland. Proc. California Weed Sci. Soc. 51:24-27.
Evans, R.A., R.E. Eckert, and B.L. Kay. 1967. Wheatgrass establishment with paraquat and tillage on downy brome ranges. Weeds 15:50-55.

Everitt, J. H., D.E. Escobar, M.A. Alaniz, and M.R Davis. 1996a. Comparison of ground reflectance measurements, airborne video, and SPOT satellite data for estimating phytomass and cover on rangelands. Geocarto Int. 11:69-76.

Everitt, J. H., D.E. Escobar, M.A. Alaniz, M.R Davis, and J.V. Richerson. 1996b. Using spatial information technologies to map Chinese tamarisk (Tamarix chinensis) infestations. Weed Sci. 44:194-201.

Everitt, J. H., G. L. Anderson, D. E. Escobar, M. R. Davis, N. R. Spencer, and R. J. Andrascik. 1995. Use of remote sensing for detecting and mapping leafy spurge (Euphorbia esula). Weed Tech. 9:599--609.

Ewel, J. 1986. Invasibility: lessons from South Florida, p. 214-230. In: H.A. Mooney and J.A. Drake (eds.), Ecology of biological invasions of North America and Hawaii. Springer-Verlag, N.Y.

Ferrell, M.A., T.D. Whitson, D.W. Koch, and A.E. Gade. 1998. Leafy spurge (Euphorbia esula) control with several grass species. Weed Technol. 12:374-380.

Flint, M.L. and R. van den Bosch. 1983. Introduction to integrated pest management. Plenum Press, New York and London.

Follett, P.A. and J.J. Duan. 1999. Non target effects of biological control. Kluwer Academic Publ., Boston, Mass.

Forcella, F. and S.J. Harvey. 1983. Eurasian weed infestation in western Montana in relation to vegetation and disturbance. Madrono 30:102-109.

Fox, J.F. 1985. Plant diversity in relation to plant production and disturbance by voles in Alaskan tundra communities. Arctic Alpine Res. 17:199-204.

Fox, M.D. and B.J. Fox. 1986. The susceptibility of natural communities to invasion,. $\mathrm{p}$. 57-66. In: R.H. Groves and J.J. Burdon (eds.), Ecology of biological invasions. Cambridge Univ. Press, Cambridge, England.

Friedel, M.H. 1991. Range condition assessment and the concept of thresholds: A viewpoint. J. Range Manage. 44:422-426.

Frye, J.D., R.E. Gaussoin, D.D. Beran, and R.A. Masters. 1997. Buffalograss establishment with preemergence herbicides. HortSci. 32:683-686.

Gates, D.H. and C. Robocker. 1960. Revegetation with adapted grasses in competition with dalmation toadflax and St. Johnswort. J. Range Manage. 13:322-326.

Goeden, R. D. and D. W. Ricker. 1986. Phytophagous insect faunas of the two most common native Cirsium thistles, C. californicum and $C$. proteanum, in southern California. Ann. Entomol. Soc. Amer. 79:953-962.

Goeden, R. D. and D. W. Ricker. 1987. Phytophagous insect faunas of native Cirsium thistles, C. mohavense, $C$. neomexicanum, and C. nidulum, in the Mojave Desert of southern California. Ann. Entomol. Soc. Amer. 80:161-175. 
Goldstein, J. 1978. The least is best pesticide strategy. The JG Press, Emmanus, Penn.

Graf, W.L. 1978. Fluvial adjustments to the spread of Tamarisk in the Colorado Plateau region. Geol. Soc. Amer. Bull. 89:1491-1501.

Gray, A.J. 1986. Do invading species have definable genetic characteristics? Phil. Trans. Roy. Soc. London. B 314:655-674.

Griffin, G.F., D.M. Stafford-Smith, S.R. Morton, G.E. Allan, K.A. Masters, and N. Preece. 1989. Status and implications of Tamarisk (Tamarisk aphylla) on the Finke River, Northern Territory, Australia. J. Environ. Manage. 29:297-315.

Grubb, P.J. 1977. The maintenance of species richness in plant communities: the importance of the regeneration niche. Biol. Rev. 52:107-145

Gunderson, L. 1999. Resilience, flexibility and adaptive management-antidotes for spurious certitude? Conserv. Ecol. 3:7.

Harley, K.L.S. and I.W. Forno. 1992. Biological control of weeds. A handbook for practitioners and students. Inkata Press, Butterworths Pty Ltd, Melbourne, Australia.

Harper, J.L. 1977. Population biology of plants. Academic Press, New York, N.Y.

Harris, P. 1988. Environmental impact of weedcontrol insects. BioScience 38:542-548.

Harris, P. 1990. Environmental impact of introduced biological control agents, p 289-300. In: M. Mackauer, L.E. Ehler, and J. Roland (eds.), Critical Issues in Biological Control. Intercept, Andover, England.

Harris, P. and D. P. Peschken. 1971. Hypericum perforatum L., St. Johns wort (Hypericaceae). Commonwealth Inst. Biol. Control Techn. Commun. 4:89.

Heywood, V.H. 1989. Patterns, extent and modes of invasion by terrestrial plants, $\mathrm{p}$ 31-55. In: J.A. Drake, H.A. Mooney, F. Di Castri, R.H. Groves, F.J. Kruger, M Rejmanek, and M. Williamson (eds.), Biological invasions: a global perspective. John Wiley \& Sons, New York, N.Y.

Hirsch, S.A. and J.A. Leitch. 1996. The impact of knapweed on Montana's economy. North Dakota State Univ. Agr. Econ. Rep 355.

Hobbs, R.J. 1989. The nature and effects of disturbance relative to invasions, p. 389-405. In: J.A. Drake, H.A. Mooney, F. Di Castri, R.H. Groves, F.J. Kruger, M. Rejmanek, and M. Williamson (eds.), Biological invasions: a global perspective. John Wiley \& Sons, New York.

Hobbs, R.J. 1991. Disturbance as a precursor to weed invasion in native vegetation. Plant Protection Quarterly 6:99-104.

Hobbs, R.J. 2000. Land-use changes and invasions. p. 55-64. In: H.A. Mooney and R.J Hobbs (eds.), Invasive species in a changing world. Island Press, Washington, D.C.

Hobbs, R.J. and L. Atkins. 1988. Effect of disturbance and nutrient addition on native and introduced annuals in plant communities in the western Australian wheatbelt Australian J. Ecol. 13:171-179.

Hobbs, R.J. and L.F. Huenneke. 1992. Disturbance, diversity, and invasion: implications for conservation. Conserv. Biol $6: 324-337$
Hobbs, R.J. and S.E. Humphries. 1995. An integrated approach to the ecology and management of plant invasions. Conserv. Biol. 9:761-770.

Hobbs, R.J. and D.A. Norton. 1996. Towards a conceptual framework for restoration ecology. Restor. Ecol. 4:93-110.

Hoffman, J.H., V.C. Moran, and D.A. Zeller. 1998. Long-term population studies and the development of an integrated management programme for control of Opuntia stricta in Kruger National Park, South Africa. J. Appl. Ecol. 35:156-160.

Holling, C. S. 1978. Adaptive environmental assessment and management. John Wiley, London, England.

Horton, W.H. 1991. Medusahead: importance, distribution, and control. p. 394-398. In: L.F. James, J.O. Evans, M.H. Ralphs, and R.D. Child (eds.), Noxious range weeds. Westview Press, San Franciso, Calif.

Howarth, F.G. 1991. Environmental impact of classical biological control. Annu. Rev. Entomol. 36:485-509.

Huffaker, C.B. and C.E. Kennett. 1959. A ten-year study of vegetational changes associated with biological control of Klamath weed. J. Range Manage. 12:69-82.

Hughes, R.F., P.M. Vitousek, and T. Tunison. 1991. Alien grass invasion and fire in the seasonal submontane zone of Hawaii. Ecol. 72:743-746.

Jackson, L.L., N. Lopoukhine, and D. Hillyard. 1995. Ecological restoration: a definition and comments. Restor. Ecol. 3:71-75.

Johnson, D.E. 1999. Surveying, mapping, and monitoring noxious weeds on rangelands. $p$. 19-35. In: Sheley, R.L. and J.K. Petroff (eds.), Biology and management of noxious rangeland weeds. Oregon State Univ. Press, Corvallis, Ore.

Johnson, H.B. and H.S. Mayeux. 1992. Viewpoint: A view on species additions and deletions and the balance of nature. J. Range Manage. 45:322-333.

Johnson, H.B., H.W. Polley, and H.S. Mayeux. 1993. Increasing $\mathrm{CO}_{2}$ and plantplant interactions: effects on natural vegetation. Vegetatio 104/105:157--170.

Johnstone, I.M. 1986. Plant invasion windows: a time-based classification of invasion potential. Bio. Rev. 61:369-394.

Jones, T.A. and D.A. Johnson. 1998 . Integrating genetic concepts into planning rangeland seedings. J. Range Manage. 51:594-606

Julien, M.H. 1992. Biological control of weeds: a world catalogue of agents and their target weeds. Academic Press, New York, N.Y.

Kedzie-Webb, S.A., R.L. Sheley, J.Borkowski, and J.S. Jacobs. 2001. Relationship between spotted knapweed and indigenous plant communities. Western North Amer. Natur. 61:43-45.

Knapp, E.E. and K.J. Rice. 1994. Starting from seed-genetic issues in using native grasses for restoration. Restor. Manage. Notes 12:40-45.
Knops, J.M.H., J.R. Griffin, and A.C. Royalty. 1995. Introduced and native plants of Hastings reservation, central coastal California: a comparison. Biol. Conserv. 71:115-123.

Kok, L. T. and W. W. Surles. 1975. Successful biocontrol of musk thistle by an introduced weevil, Rhinocyllus conicus. Environ. Entomol. 4:1025-1027.

Kruger, F.J., D.M. Richardson, and B.W. van Wilgen. 1986. Processes of invasion by plants, p. 145-155. In: I.A.W. Macdonald, F.J. Kruger, and A.A. Ferrar (eds.), The ecology and management of biological invasions in South Africa. Oxford Univ. Press, Cape Town, South Africa.

Lacey, C.A., J.R. Lacey, P.K. Fay, J.M. Story, and D.L. Zamora. 1995. Controlling knapweed in Montana rangeland. Montana State Coop. Ext. Serv. Circular-311.

Lacey, J.R., C.B. Marlow, and J.R. Lane. 1989. Influence of spotted knapweed (Centaurea maculosa) on surface runoff and sediment yield. Weed Technol. 3:627-631.

Landgraf, B.K., P.K. Fay, and K.M. Havstad. 1984. Utilization of leafy spurge (Euphorbia esula) by sheep. Weed Sci. 32:348-352.

Lawton, R.H. 1986. Are there assembly rules for successional communities? p. 225-244. In: A.J. Gray, M.J. Crawley, and P.J. Edwards (eds.), Colonization, succession and stability. Blackwell Scientific Publ. Oxford, England.

Laycock, W.A. 1991. Stable states and thresholds of range condition on North American rangelands: A viewpoint. J. Range Manage. 44:427-433.

Leitch, J.A., F.L. Leistriz, and D.A. Bangsund. 1996. Economic effect of leafy spurge in the upper great plains: methods, models, and results. Impact Assess. 14:419-433.

Lesica, P. and F.W. Allendorf. 1999. Ecological genetics and the restoration of plant communities: mix and match? Restor. Ecol. 7:42-50.

Linhart, Y.B. and M.C. Grant. 1996. Evolutionary significance of local genetic differentiation in plants. Annu. Rev. Ecol. Syst. 27:237-277.

Lodge, D.M. 1993. Biological invasions: lessons for ecology. Trends in Ecology and Evol. 8:133-137.

Lonsdale, W.M. 1993. Rates of spread of an invading species - Mimosa pigra in northern Australia. J. Ecol. 81:513-521.

Lonsdale, W.M. 1994. Inviting trouble: introduced pasture species in northern Australia. Australian J. Ecol. 19:345-354.

Lonsdale, W.M. 1999. Global patterns of plant invasions and the concept of invasibility. Ecol. 80:1522-1536.

Lonsdale, W.M. and A.M. Lane. 1994. Tourist vehicles as vectors of weed seeds in Kakadu National park, northern Australia. Biol. Conserv. 69:277-283.

Loope, L.L. and P.G. Sanchez. 1988. Biological invasions of arid land nature reserve. Biol. Conserv. 44:95-118. 
Louda, S. and R.A. Masters. 1993. Biological control of weeds in Great Plains rangelands. Great Plains Res. 3:215-247.

Louda, S., D. Kendall, J. Connor, and D. Simberloff. 1997. Ecological effects of an insect introduced for the biological control of weeds. Sci. 277:1088-1090.

Luken, J. O. 1990. Directing Ecological Succession. Chapman and Hill, London, England.

Lym, R.G. and C.G. Messersmith. 1993. Fall cultivation and fertilization to reduce winterhardiness of leafy spurge (Euphorbia esula) Weed Sci. 41:441-446.

Lym, R.G. and D.A. Tober. 1997. Competitive grasses for leafy spurge (Euphorbia esula) reduction. Weed Technol. 11:787-792.

Lym, R.G., K.K. Sedivec, and D.R. Kirby. 1997. Leafy spurge control with angora goats and herbicides. J. Range Manage. 50:123-128

Macdonald, I.A.W., F.J. Powrie, and W.R. Siegfried. 1986. The differential invasion of South Africa's biomes and ecosystems by alien plants and animals, p. 209-225. In I.A.W. Macdonald, F.J. Kruger, and A.A Ferrar (eds.), The ecology and management of biological invasions in South Africa. Oxford University Press, Cape Town, South Africa.

Mack, R.N. 1985. Invading plants: their potential contribution to population biology, $\mathrm{p}$ 127-143. In: J. White (ed.), Studies in plant demography: A festschrift for John L. Harper. Academic Press, London, England.

Mack, R.N. 1989. Temperate grasslands vulnerable to plant invasions: characteristics and consequences, p. 155-179. In: J.A. Drake, H.A. Mooney, F. Di Castri, R.H. Groves, F.J. Kruger, M. Rejmanek, and M. Williamson (eds.), Biological invasions: a global perspective. John Wiley \& Sons, New York, N.Y.

Mack, R.N. 1996. Predicting the identity and fate of plant invaders: emergent and emerging approaches. Biol. Conser. 78:107-121.

Masters, R.A. and S.J. Nissen. 1998. Revegetating leafy spurge (Euphorbia esula L.)-infested grasslands with native tallgrasses. Weed Technol. 12:381-390.

Masters, R.A., D.D. Beran, and and F. Rivas-Pantoja. 1998. Leafy spurge (Euphorbia esula L.) response to AC 263,222. Weed Technol. 12:602-609.

Masters, R.A., D.D. Beran, and and R.E. Gaussoin. 2001. Restoring tallgrass prairie species mixtures on leafy spurge-infested rangelands. J. Range Manage. 54:362-369.

Masters, R.A., S.J. Nissen, R.E. Gaussoin, D.D. Beran, and R.N. Stougaard. 1996. Imidazolinone herbicides improve restoration of Great Plains grasslands. Weed Technol. 10:392-403.

Messersmith, C.G. and S.W. Adkins. 1995 Integrating weed-feeding insects and herbicides for weed control. Weed Technol. 9:199-208

Millar, C.I. and W.J. Libby. 1989. Disneyland or native ecosystem: genetics and the restorationist. Restor. Manage. Notes 7:18-24.
Miller, R.F., T.J. Svejcar, and N.E. West. 1994. Implications of livestock grazing in the intermountain sagebrush region: plant composition, p. 101-146. In: M.Vavra, W.A. Laycock, and R.D. Pieper (eds.), Ecological implications of livestock herbivory in the west. Soc. Range Management. Denver, Colo.

Moody, M.E. and R.N. Mack. 1988. Controlling the spread of plant invasions: the importance of nascent foci. J. Appl. Ecol. 25:1009-1021.

Mooney, H.A. and J.A. Drake. 1989. Biological invasions: a SCOPE program overview, p. 491-506. In: J.A. Drake, H.A. Mooney, F. Di Castri, R.H. Groves, F.J. Kruger, M. Rejmanek, and M. Williamson (eds.), Biological invasions: a global perspective. John Wiley \& Sons, New York, N.Y.

Morse, L.E., J.T. Kartesz, and L.S. Kutner. 1995. Native vascular plants. p 205-209. In: E.T. LaRoe, G.S. Farris, C.E. Puckett, P.D. Doran, and M.J. Mac (eds.), Our living resources: a report to the Nation on the distribution, abundance, and health of US plants, animals, and ecosystems. Washington D.C., USDI, Nat. Biolo. Serv.

Munda, B.D. and S.E. Smith. 1995. Genetic variation and revegetation strategies for desert rangeland ecosystems, p. 288-291. In: B.A. Roundy, E.D. McArthur, J.S. Haley, and D.K. Mann (Compilers), Proc. Wildland shrub and arid land revegetation symposium. USDA Forest Serv. Gen. Tech. Rep. INTGTR-315. Ogden, Ut.

Naeem, S, L.J. Thompson, S.P. Lawler, J.H. Lawton, and R.M. Woodfin. 1994. Declining biodiversity can alter the performance of ecosystems. Nature 368:734-737.

Naylor, R.L. 2000. The economics of alien species invasions. p. 55-64. In: H.A. Mooney and R.J. Hobbs (eds.), Invasive species in a changing world. Island Press, Washington, D.C.

Nelson, J.A., R.G. Lym, and C.G. Messersmith. 1998. Integration of herbicides with the biological agent Aphthona nigriscutis for leafy spurge control. Proc. Western Weed Sci. Soc. 51:132.

Nissen, S.J., R.A. Masters, D.J. Lee, and M.L. Rowe. 1995. DNA-based marker systems to determine genetic diversity of weedy species and their application to biocontrol. Weed Sci. 43:504-513.

Nobel, I.A. 1989. Attributes of invaders and the invading process: terrestrial and vascular plants, p. 301-313. In: J.A. Drake, H.A. Mooney, F. Di Castri, R.H. Groves, F.J. Kruger, M. Rejmanek, and M. Williamson (eds.), Biological invasions: a global perspective. John Wiley \& Sons, New York, N.Y.

Noss, R.F. 1991. From endangered species to biodiversity, p. 227-246. In: K. Kolm (ed.), Balancing on the brink of extinction: the endangered species act and lessons from the future. Island Press, Washington, D.C.

Okubo, A. 1980. Diffusion and ecological problems: mathematical models. SpringerVerlag, Berlin, Germany.
Orians, G.H. 1986. Site characteristics promoting invasions and systems impacts of invaders, p. 133-148. In: H.A. Mooney and J.A. Drake (eds.), Ecology of biological invasions of North America and Hawaii. Springer-Verlag, New York, N.Y.

Palmer, M.W. and T. Maurer. 1997. Does diversity beget diversity? A case study of crops and weeds. J. Veg. Sci. 8:235-240.

Panetta, F.D. 1993. A system for assessing proposed plant introductions for weed potential. Plant Protection Quarterly 8:10-14.

Parendes, L.A. and J.A. Jones. 2000. Light availability, dispersal, and exotic plant invasion along roads and streams in the H.J. Andrews Experimental Forest, Oregon. Conserv. Biol. 14:64-75.

Patterson, D.T. 1995. Weeds in a changing climate. Weed Sci. 43:685-701.

Peart, D.R. and T.C. Foin. 1985. Analysis and prediction of population and community change: a grassland case study, p. 313-339. In: White, J. (ed.), The population structure of vegetation. Dr. W. Junl, Dordrecht, The Netherlands.

Petraitis, P.S., R.E. Latham, and R.A. Niesenbaum. 1989. The maintenance of species diversity by disturbance. Quart. Rev. Biol. 64:393-418.

Pickard, J. 1984. Exotic plants on Lord Howe Island: distribution in space and time. $\mathrm{J}$. Biogeogr. 11:181-208.

Pickett, S.T.A., S.L. Collins, and J.J. Armesto. 1987. Models, mechanisms and pathways of succession. Bot. Rev. 53:335-371.

Pimental, D. 1982. Perspectives of integrated pest management. Crop Protection 1:5-26.

Pimental, D., L. Lach, R. Zuniga, and D. Morrison. 2000. Environmental and economic costs of nonindigenous species in the Untied States. BioScience 50:53-65.

Planty-Tabacchi, A., E. Tabacchi, R.J. Naiman, C. DeFerrari, and H. Decamps. 1996. Invasibility of species rich communities in riparian zones. Conserv. Biol. 10:598-607.

Pyne, S.J. 1984. Introduction to wildland fire. John Wiley \& Sons, New York, N.Y.

Quimby, P. C., W. L. Bruckart, C. J. DeLoach, L. Knutson, and M. H. Ralphs. 1991. Biological control of rangeland weeds, p. 84-102. In: L.F. James, J.O. Evans, M.H. Ralphs and R.D. Child (eds.), Noxious range weeds. Westview Press, Boulder, Colo.

Radosevich, S., J. Holt, and C. Ghersa. 1997. Weed ecology: implications for management. John Wiley and Sons, New York.

Randall, J.M. 1997. Defining weeds of natural areas, p. 18-25. In: J.O. Luken and J.W. Thieret (eds.), Assessment and management of plant invasions. Springer, New York, N.Y.

Reichard, S.H. and C.W. Hamilton. 1997. Predicting invasions of woody plants introduced into North America. Conserv. Biol. 11:193-203.

Rejmanek, M. 1989. Invasibility of plant communities, p. 369-388. In: J.A. Drake, H.A. Mooney, F. Di Castri, R.H. Groves, F.J. Kruger, M. Rejmanek, and M. Williamson (eds.), Biological invasions: a global perspective. John Wiley \& Sons, New York, N.Y. 
Rejmanek, M. and D.M. Robinson. 1996. What attributes make some plant species more invasive. Ecol. 77:1655-1661.

Renz, M. and J. DiTomaso. 1999. Biology and control of perennial pepperweed. Proc. California Weed Sci. Soc. 51:13-16.

Rinella, M. J. , J. S. Jacobs, R. L. Sheley, and J. J. Borkowski. 2001. Spotted knapweed response to season and frequency of mowing. J. Range Manage. 54:52-56.

Rivas-Pantoja, F., R.A. Masters, and D.D. Beran. 1997. Influence of planting date and herbicides on native tallgrass establishment. Soc. Range Manage., Rapid City, S.D. Abstr. p. 63 .

Robinson, G.R., J.F. Quinn, and M.L. Stanton. 1995. Invasibility of experimental habitat islands in a California winter annual grassland. Ecol. 76:786-794.

Ross, M.A. and C.A. Lembi. 1999. Applied weed science. Prentice Hall, Upper Saddle River, N.J.

Roush, R.T. 1990. Genetic variation in natural enemies: Critical issues for colonization in biological control, p. 263-287. In: M. Mackauer, L.E. Ehler and J. Roland (eds.), Critical issues in biological control. Intercept Ltd, England.

Rowe, M.L., D.J. Lee, S.J. Nissen, B.M. Bowditch, and R.A. Masters. 1997. Genetic variation in North American leafy spurge (Euphorbia esula) determined by genetic markers. Weed Sci. 45:446-454.

Rykiel, E.J. 1985. Towards a definition of ecological disturbance. Australian J. Ecol. 10:361-365.

Saghoff, M. 1995. Carrying capacity and ecological economics. BioScience 45:610-620.

Schwartz, M.W. and J.M. Randall. 1995. Valuing natural areas and controlling non-indigenous plants. Nat. Areas J. 15:98-100

Scifres, C.J. 1986. Integrated management systems for improvement of rangeland, $p$ 227-260. In: M.A. Sprague and G.B. Triplett (eds.), No tillage and surface tillage agriculture. John Wiley \& Sons, New York, N.Y.

Scifres, C.J. 1987. Decision-analysis approach to brush management planning: Ramifications for integrated range resources management. J. Range Manage. 40:482-490.

Scifres, C.J., W.T. Hamilton, J.M. Inglis, and J.R. Conner. 1983. Development of integrated brush management systems (IBMS): Decision-making processes, $\mathrm{p}$. 97-104. In: K. McDaniel (ed.), Proceedings brush management symposium. Soc. Range Manage. Albuquerque, N.M.

Selleck, G.W., R.T. Coupland, and C. Frankton. 1962. Leafy spurge in Saskatchewan. Ecol. Monogr. 32:1-29.

Shaw, W.C. 1982. Integrated weed management systems technology for pest management. Weed Sci. 30 (Suppl.):2-12.

Sheley, R.L. and J.K. Petroff. 1999. Biology and management of noxious rangeland weeds. Oregon State Univ. Press. Corvalis, Ore.

Sheley, R.L., J.S. Jacobs, and D.E. Lucas. 2001. Revegetating spotted knapweed infested rangeland in a single entry entry. J. Range Manage. 54:144-151.
Sheley, R.L., B.H. Mullin, and P.K. Fay. 1995. Managing riparian weeds. Rangelands 17:154-157.

Sheley, R.L., T.J. Svejcar, and B.D. Maxwell. 1996. A theoretical framework for developing successional weed management strategies for rangeland. Weed Technol. 10:766-773.

Sheppard, A.W. 1992. Predicting biological weed control. Trends Ecol. Evol. 7:290-296.

Silvertown, J. 1981. Microspatial heterogeneity and seedling demography in species-rich grassland. New Phytol. 88:117-128.

Simberloff, D. 1989. Which insect introductions succeed and which fail? p. 61-75. In: J.A. Drake, H.A. Mooney, F. Di Castri, R.H. Groves, F.J. Kruger, M. Rejmanek, and M. Williamson (eds.), Biological invasions: a global perspective. John Wiley \& Sons, New York, N.Y.

Society for Ecological Restoration. 1994. Project policies of the Society for Ecological Restoration. Restor. Ecol. 2:132-133.

Stock, W.D. and N. Allsopp. 1992. Functional perspective of ecosystems, p. 241-259. In: R.M. Cowling (ed.), The ecology of fynbos. Nutrients, fire, and diversity. Oxford Univ. Press, Cape Town, South Africa.

Stohlgren, T.J., K.A. Bull, Y. Otsuki, C.A. Villa, and M. Lee. 1998. Riparian zones as havens for exotic plant species in the central grasslands. Plant Ecol. 138:113-125.

Stohlgren, T.J., D. Binkley, G.W. Chong, M.A. Kalkhan, L.D. Schell, K.A. Bull, Y. Otsuki, G. Newman, M. Baskin, and Y. Son. 1999. Exotic plant species invade hot spots of native plant diversity. Ecol. Monogr. $69 \cdot 25-46$.

Stuth, JW. and M. Stafford Smith. 1993. Decision support for grazing lands: an overview. p. 1-36. In: J.W. Stuth, and B.G. Lyons (eds.), Decision support for the management of grazing lands. Parthenon Publ. Group, New York, N.Y.

Sutherst, R.W. 2000. Climate change and invasive species: a conceptual framework, $p$. 211-240. In: H.A. Mooney and R.J. Hobbs (eds.), Invasive species in a changing world. Island Press, Washington, D.C.

Svejcar, T. and R.J. Tausch. 1991. Anaho Island, Nevada: a relic area dominated by annual invader species. Rangelands 13:233-236.

Task Group on Unity in Concepts and Terminology. 1995. New concepts for assessment of rangeland condition. J. Range Manage. 48:271-282.

Thill, D.C., J.M. Lish, R.H. Callihan, and E.J. Bechinski. 1991. Integrated weed management-a component of integrated pest management: A critical review. Weed Technol. 5:648-656.

Thompson, M.J. 1996. Winter foraging response of elk to spotted knapweed removal. Northwest Sci. 70:10-19.

Thompson, W.M., S.J. Nissen, and R.A. Masters. 1998. AC 263,222 absorption and fate in leafy spurge (Euphorbia esula). Weed Sci. 46:510-513.
Tilman, D. 1996. Biodiverstiy: population versus ecosystem stability. Ecol. 77:350-363.

Tilman, D. 1997. Community invasibility, recruitment limitation, and grassland biodiversity. Ecol. 78:81-92.

Tilman, D. 1999. The ecological consequences of changes in biodiversity: a search for general principles. Ecol. 80:1455-1474.

Trammel, M.A. and J.L. Butler. 1995. Effects of exotic plants on native ungulate use of habitat. J. Wildl. Manage. 59:808-816.

Tyser, R.W. and C.H. Key. 1988. Spotted knapweed in natural area fescue grasslands: an ecological assessment. Northwest Sci. 62:151-160.

Trombulak, S.C. and C.A. Frissell. 2000. The ecological effects of roads on terrestrial and aquatic communities: a review. Conserv. Biol. 14:18-30.

Turner, C.E., R.W. Pemberton, and S.S. Rosenthal. 1987. Host utilization of native Cirsium thistles (Asteraceae) by the introduced weevil Rhinocyllus conicus (Coleoptera: Curculionidae) in California. Environ. Entomol. 16:111-115.

U.S. Congress, Office of Technology Assessment. 1993. Harmful Non-Indigenous Species in the United States. U.S. Government Printing Office, Washington, D.C.

Vallentine, J.F. 1989. Range development and improvements. 3rd Ed. Academic Press, San Diego, Calif.

van Andel, J. and J.P. van den Berg. 1987. Disturbance of grasslands, p. 3-13. In: J. van Andel, J.P. Baker, and R.W. Snaydon (eds.), Disturbance in grasslands: causes, effects, and processes. Junk, Dordrecht, The Netherlands.

Vavilov, N. I. 1992. Origin and geography of cultivated plants. Cambridge Univ. Press, New York, N.Y.

Versfeld, D.B. and B.W. van Wilgen. 1986. Impact of woody aliens on ecosystem properties, p. 239-246. In: I.A.W. Macdonald, F.J. Kruger, and A.A. Ferrar (eds.), The ecology and management of biological invasions in South Africa. Oxford University Press, Cape Town, South Africa.

Vitousek, P.M. and L.R. Walker. 1989 Biological invasion by Myrica faya in Hawaii: plant demography, nitrogen fixation, ecosystem effects. Ecol. Monogr. 59:247-265.

Vitousek, P.M., H.A. Mooney, J. Lubchenco, and J.M. Melillo. 1997. Human domination of earth's ecosytems. Sci. 277:494-499.

Vogel, K.P. 2000. Improving warm-season forage grasses using selection, breeding, and biotechnology, p. 83-106. In: K.J. Moore and B.E. Anderson (eds.), Warm-season grasses: research trends and issues. Crop Sci. Soc. Amer. Spec. Publ. No. 30. Madison, Wis.

Vogel, K.P., H.J. Gorz, and F.A. Haskins. 1989. Breeding grasses for the future, $\mathrm{p}$. 105-122. In: D.A. Sleper et al. (eds.), Contributions from breeding forage and turf grasses. Crop Sci. Soc. Amer. Spec. Publ. 15. Madison, Wis. 
Wade, M. 1997. Predicting plant invasions: making a start, p. 1-18. In: J.H. Brock, M. Wade, P. Pysek, and D. Green (eds.), Plant invasions: studies from North America and Europe. Backhuys Publishers, Lieden, The Netherlands.

Walker, B.H. 1992. Biological and ecological redundancy. Conserv. Biol. 6:18-23.

Walker, J.W. 1994. Multi-species grazing: the ecological advantage. Sheep Res. J. Special Issue: 52-64.

Walker, J.W. 1995. Viewpoint: Grazing management and research now and in the next millennium. J. Range Manage. 48: 350-357.

Walker, J.W., S.L. Kronberg, S.L. AlRowaily, and N.E. West. 1994. Comparison of sheep and goat preferences for leafy spurge. J. Range Manage. 47:429-434.

Walker, L.R. and S.D. Smith. 1997. Impacts of invasive plants on community and ecosystem properties. p. 69-86. In: J.O. Luken and J.W. Thieret (eds.), Assessment and management of plant invasions. Springer, New York, N.Y.

Walker, R. H. and G. A. Buchanan. 1982. Crop manipulation in integrated weed management systems. Weed Sci. 30:17-24.

Walters, C. 1986. Adaptive management of renewable resources. McGraw Hill, New York, N.Y

Watt, A.S. 1947. Pattern and process and natural disturbance in vegetation. J. Ecol. 35:1-22.
Weaver, J.E. and F.E. Clements. 1938. Plant ecology. McGraw-Hill, New York, N.Y.

Westoby, M., B. Walker, and I. Noy-Meir. 1989. Opportunistic management for rangelands not at equilibrium. J. Range Manage. 42:266-274

Whisenant, S.G. 1990. Changing fire frequencies on Idaho's Snake River plains: ecological and management implications, p. 4-10. In: Proc. Symp. Cheatgrass Invasion, Shrub Die-off and other Aspects of Shrub Biology and Management. Gen. Techn. Rep. INT276. United States Forest Service, Washington, D.C.

Whisenant, S.G. 1999. Reparing damaged wildlands: a process-oriented, landscapescale approach. Cambridge University Press, Cambridge, England.

White, P.S. and S.T.A. Pickett. 1985. Natural disturbance and patch dynamics: an introduction, p. 3-13. In: White, P.S. and S.T.A. Pickett (eds.), The ecology of natural disturbance and patch dynamics. Academic Press, New York, N.Y.

Whitson, T.S. and D.W. Koch. 1998. Control of downy brome (Bromus tectorum) with herbicides and perennial grass competition. Weed Technol. 12:391-396.

Williamson, M. 1989. Mathematical models of invasion, p. 329-350. In: J.A. Drake, H.A. Mooney, F. Di Castri, R.H. Groves, F.J. Kruger, M. Rejmanek, and M. Williamson (eds.), Biological invasions: a global perspective. John Wiley \& Sons, New York, N.Y.
Williamson, M. 1996. Biological invasions. Chapman \& Hall, New York, N.Y.

Wilson, R. G. and S. D. Kachman. 1999. Effect of perennial grasses on Canada thistle (Cirsium arvense) control. Weed Technol. 13:83-87.

Woods, K.D. 1993. Effects of invasion by Lonicera tatarica $\mathrm{L}$. on herbs and tree seedlings in four New England forests. Amer. Midl. Natur. 130:62-74.

Wright, H.A. and A.W. Bailey. 1982. Fire ecology. John Wiley and Sons, New York, N.Y.

Young, J.A. and W.S. Longland. 1996. Impact of alien plants on Great Basin rangelands. Weed Technol. 10:384-391.

Young, J.A., R.A. Evans, and R.E. Eckert. 1969. Wheatgrass establishment with tillage and herbicides in a mesic medusahead community. J. Range Manage. 22:151-155.

Zamora, D.L., D.C. Thill, and R.E. Eplee. 1989. An eradication plan for plant invasions. Weed Technol. 3:2-12.

Zwolfer, H., M.A. Ghani, and V.P. Rao. 1976. Foreign exploration and importation of natural enemies, p. 189-207. In: C.B. Huffaker and P.S. Messenger (eds.), The theory and practice of biological control. Academic Press, New York, N.Y. 